\title{
The Stress of Having A Single Monetary Policy in Europe
}

\author{
JAN-EGBERT STURM \\ TIMO WOLLMERSHÄUSER
}

CESIFO WORKING PAPER NO. 2251

CATEGORY 6: MONETARY Policy AND InTERnATIONAL FinANCE

MARCH 2008

\footnotetext{
An electronic version of the paper may be downloaded

- from the SSRN website: Www.SSRN.com

- from the RePEc website: $\quad$ www.RePEc.org

- from the CESifo website: www.CESifo-group.org/wp
} 


\title{
The Stress of Having A Single Monetary Policy in Europe
}

\begin{abstract}
This paper estimates forward-looking Taylor rules for the euro area. Using the asymmetries in inflation and cyclical output developments across countries, we investigate the adequacy of the single monetary policy for each of the European Monetary Union (EMU) member countries. Notable differences emerge across the countries. Taking a euro area perspective, we also show that it depends upon the underlying country weighting scheme in the monetary decision process of the ECB whether or not there has been a synchronisation of business and inflation cycles among the EMU member countries over the years. Finally, we produce an estimate of the actual policy weights the ECB has implicitly attached to each of the member countries. Developments in small member countries have received more than proportional weights in actual monetary policy decisions of the ECB.
\end{abstract}

JEL Code: C22, E52, E58.

Keywords: Taylor rule, monetary policy, ECB, stress, business cycle synchronisation.

Jan-Egbert Sturm

KOF Swiss Economic Institute

ETH Zurich

WEH D 4

8092 Zurich

Switzerland

sturm@kof.ethz.ch
Timo Wollmershäuser

Ifo Institute for Economic Research at the University of Munich

Poschingerstrasse 5

81679 Munich

Germany

wollmershaeuser@ifo.de

February 2008

We thank Helge Berger, Jan Jacobs and participants of seminars at the Ifo Institute, the Universities of Groningen, Osnabrück and Würzburg, and the ECB for helpful comments. The usual disclaimer applies. 


\section{Introduction}

A topic regularly discussed amongst ECB watchers is the cost for the euro area countries of having a common monetary policy. ${ }^{1}$ A single monetary policy almost by definition implies that policy will not be appropriate for all member countries at the same time. The larger the difference between the actual monetary policy and the monetary policy preferred by individual member countries, the more likely it is that the ECB will be under political pressure. To our knowledge, Clarida et al. (1998) were the first to associate this difference to what they call monetary stress and - in their case - use it to analyse the causes of the 1992/93 crisis of the European Monetary System (EMS). ${ }^{2}$ Hence, stress in a monetary system occurs when - for whatever reason - a central bank is unable to set its policy instrument optimally.

In this paper, we follow up on this and provide monetary stress indicators for the euro area. Their evolution over time will supply important information concerning the adequacy of the single monetary policy for each of the EMU member countries. Furthermore, it allows us to construct a single indicator for business and inflation cycle synchronisation in the euro area as relevant for the monetary authorities. In this way we shed light on the question whether the euro area is indeed a self-enforcing optimal currency area and, at the same time, get a feeling for the country weighting scheme implicitly used by the ECB Governing Council in their monetary decisions. Following the work of Sauer and Sturm $(2003,2007)$, we use a state-of-theart Taylor rule framework which is both forward-looking and based upon real-time information for this.

Using market expectations with respect to economic growth and inflation, we first of all conclude that stress levels differ considerably across the EMU member countries. Furthermore, under the assumption that the ECB takes a purely European perspective, we do not find that business cycles have been converging since the adoption of a common monetary policy by the ECB. In other words, when the ECB implicitely weighs participating countries according to their economic size, there is no evidence that the overall cyclical stress in the euro area has declined over time. However, according to, e.g. Berger (2006) the misrepresentation of economic size in the voting distribution of

\footnotetext{
${ }^{1}$ Of course, there are also benefits associated to having a single currency. In this paper, however, we fully concentrate upon (part of) the cost side.

${ }^{2}$ Following the literature on foreign exchange markets and central bank intervention in which the term "exchange market pressure" plays an important role, another way to label this difference would be "interest rate pressure" or "monetary market pressure" (see e.g. Weymark, 1996, Tanner, 2006, and Van Poeck et al., 2007). However, in line with Clarida et al. (1998), we will henceforth label this difference "country-specific monetary stress".
} 
the ECB Governing Council is quite large. When we take a more politicaloriented approach in which smaller member countries receive a weight larger than suggested by their economic size our previous conclusion changes and business cycles have become more synchronised over time.

Hence, the crucial question is which implicit weighting scheme is more relevant in practice? It is difficult to answer this question conclusively, but when we assume that the burden of the common monetary policy is over time evenly distributed across its member countries, especially the larger countries appear to have received a relatively small political weight, i.e. relative to their economic size. This implies a relatively large weight for the smaller economies in EMU monetary policy decisions. Also in such a scenario, business cycles tend to have become more synchronised over time.

This paper is organized as follows. The next section describes the way in which we construct our monetary stress indicators. Section 3 discusses the data in some detail, while section 4 presents our empirical results. After reporting our Taylor rule estimates for the euro area, we distinguish between a country-specific point of view (section 4.3) and an area wide perspective (section 4.4). Section 4.5 discusses the main findings and the final section offers some concluding comments.

\section{Theoretical framework}

\subsection{Forward-looking monetary decision rule}

Taylor (1993) established a relationship between the central bank interest rate and two indicators: the deviation of inflation from its target and the output gap. The Taylor rule interest rate is generally seen as a benchmark interest rate for actual monetary policy.

When using so-called Taylor rules to analyse the appropriate stance of monetary policy, it is important to take a forward-looking perspective. It is generally recognised that it will take several quarters for a policy change today to have its full-blown effect on the real economy and actual inflation rates. Hence, instead of focusing too much on today's inflation rate, the central bank is likely to put substantial weight on expected future developments in their decision-making process. Indeed, when exploring different ECB Taylor rules for the euro area, Sauer and Sturm $(2003,2007)$ conclude that only forward-looking specifications (by either taking expectations derived from surveys or assuming rational expectations) give estimated Taylor rules in line with both theoretical models and communicated behaviour of the ECB itself. Similar conclusions are drawn by Castelnuovo (2007) and 
Gorter et al. (2007). Hence, we explore forward-looking Taylor rules based on the idea that in order to ensure medium-term price stability, the central bank interest rate seeks to keep expected output and inflation fluctuations at their target rates.

In our formulation, real economic developments are proxied by growth rates instead of output levels, as is more common in the Taylor rule literature. Under the assumption of constant potential output growth, this implies that instead of the level of the output gap, we include the expected change in the output gap. To underline this difference, we therefore label our estimated reaction function as one of the "modified" Taylor rule. For instance, Walsh (2003) and Geberding et al. (2004) have argued that such a "speed limit policy", or "difference rule", performs quite well in the presence of imperfect information about the output gap. Given that output gaps are notoriously difficult to measure and tend to be revised substantially over time, this appears quite plausible. Growth rates, on the other hand, are much less prone to data revisions. Secondly, the use of growth cycles has the advantage that they in general have a clear lead over classical cycles. Furthermore, most theoretical models abstract from long-run growth. When allowing for trend growth, it is possible to specify Taylor rules in terms of output growth rates. Finally, expectations and forecasts are normally formulated in terms of growth rates and are therefore readily available. Any deviations of the expected inflation and growth rates from their targets will induce the central bank to adjust the interest rate.

The formula for the modified Taylor rate $i_{j, t}^{*}$ is as follows:

$$
i_{j, t}^{*}=\alpha_{j} \Delta \bar{y}_{j, t}+\bar{\pi}_{j, t}+\beta_{j}\left(E_{t} \pi_{j, t+k}-\bar{\pi}_{j, t}\right)+\gamma_{j}\left(E_{t} \Delta y_{j, t+k}-\Delta \bar{y}_{j, t}\right),
$$

where $j$ denotes the country and $E_{t} x_{j, t+k}$ refers to the expected value of variable $x$ in $k$ months time based on information at time $t$. If the shortterm interest rate is above the modified Taylor interest rate, it indicates that monetary policy is more restrictive than one would expect based on anticipations of inflation and output growth. If the actual interest rate is below the modified Taylor rate, it indicates that monetary policy is more expansionary than the inflation and economic growth expectations would suggest.

The first two terms define the time-invariant neutral nominal interest rate in country $j$, which corresponds to the interest rate that would prevail if all prices were flexible. Woodford (2003) refers to this rate as the Wicksellian natural rate of interest. Put more practically, the neutral interest rate is equal to the nominal interest rate that would prevail if inflation is at target and output growth equals its trend rate. In Equation (1), it is the sum of the 
neutral real interest rate in country $j$ and the inflation target. In line with Woodford (2003), Laubach and Williams (2003) and Garnier and Wilhelmsen (2005), we assume the neutral real interest rate to be a linear function of the trend growth rate of expected real GDP in country $j, \Delta \bar{y}_{j, t}$.

The last two terms in Equation (1) are the feedback terms, which prescribe the central bank how to adjust its operating target over time whenever the expected inflation gap $\left(E_{t} \pi_{j, t+k}-\bar{\pi}_{j, t}\right)$ or the expected change in the output gap $\left(E_{t} \Delta y_{j, t+k}-\Delta \bar{y}_{j, t}\right)$ deviate from zero. The more expected growth exceeds trend growth, the higher the modified Taylor interest rate will be. In the same way, the more expected inflation exceeds its target, the higher the Taylor interest rate will be. Hence, the coefficients $\beta$ and $\gamma$ are the weights given by the central bank to deviations from the inflation and growth targets.

Especially since the early 1990s, it is in practice commonly observed that central banks worldwide tend to move policy interest rates in small steps without reversing direction quickly. To capture such interest rate smoothing, the previous equation is viewed as the mechanism by which the target interest rate, $i_{j, t}^{*}$, is determined. The actual interest rate $i_{j, t}$ adjusts only slowly to this target according to

$$
i_{j, t}=\rho_{j} i_{j, t-1}+\left(1-\rho_{j}\right) i_{j, t}^{*}+v_{t},
$$

where $\rho_{j}$ is the smoothing parameter, $v_{t}$ the error term and $i_{j, t}^{*}$ is given by Equation (1). Some recent papers argue that the observed inertia in interest rates may also be explained by serially correlated error terms in the policy rule, which represent omitted shocks to policy behavior, like financial crises (see for example Rudebusch, 2002):

$$
v_{t}=\delta_{j} v_{t-1}+\varepsilon_{t}
$$

where $\delta_{j}$ is the serial correlation parameter and $\varepsilon_{t}$ is an independent identically distributed error term. Following English et al. (2003) we combine the partial adjustment model and the serial correlation model to obtain a nested empirical Taylor rule model that consists of Equations (1), (2) and (3).

\subsection{Monetary stress indicator}

As the ECB has to take into account developments on the aggregate European level, asymmetries in inflation and GDP developments across countries will generate differences between the actual optimal interest rate and the optimal interest rate that would have resulted if national central banks were able to respond to national inflation and GDP growth. We call this difference country-specific monetary stress,

$$
S_{j, t}=i_{E A, t}^{*}-i_{j, t}^{*} .
$$


It is defined as the gap between the optimal area-wide interest rate, $i_{E A, t}^{*}$, and the optimal interest rate that would prevail in country $j$, if it was able to follow a country-specific interest rate policy, $i_{j, t}^{*}$. A negative value for $S_{j, t}$ implies that actual monetary policy of the ECB for country $j$ is more accommodative than what could be expected using country-specific data. If, on the other hand, $S_{j, t}$ is positive, actual monetary policy appears too tight for country $j$.

The main problem related to the calculation of country-specific stress is that national monetary policy cannot be observed in the 1999-2006 period, i.e. the period under investigation. In theory, an optimal monetary policy rule for a country can be obtained from the minimisation of an intertemporal loss function (over expected future deviations of some target variables from their target levels) subject to the current state and the structure of the economy. Ball (1999) and Woodford (2003, Ch. 7) show that the resulting reaction coefficients are a function of both, structural and preference parameters. The former relate to how the economy works, whereas the latter reflect the relative weights of the target variables in the central bank's loss function.

In implementing this concept, Flaig and Wollmershäuser (2007) take the optimal monetary policy rule to correspond to the policy rule that was adopted by the country in the pre-EMU period. They thereby take an extreme position. Besides keeping the structural parameters constant over time and country-specific, they also assume that the euro was forced upon the participating countries and that each individual nation would prefer a central bank with a similar behaviour as its own before the establishment of the Monetary Union. Hence, they also keep the preference parameters in the policy rule constant over time and country-specific.

We, on the other hand, assume that all EMU member countries voluntarily decided to participate, thereby signalling that in principle the institutional set-up of the ECB - and thereby the preference parameters as implied by the ECB - is preferred over the situation prevailing before the euro. Furthermore, we assume that the euro area economies function in rather similar ways, i.e. their structural parameters are very much alike. From this follows that national central banks would implement a similar policy rule as the ECB, if they had the choice to do so, implying that we only need to estimate the parameters of the ECB reaction function using aggregate euro area data 
over the actual ECB operating period. Thus, stress can be computed as

$$
\begin{aligned}
S_{j, t} & =\left[\bar{\pi}_{E A, t}-\bar{\pi}_{j, t}\right]+ \\
& +\left[\widehat{\alpha}_{E A} \Delta \bar{y}_{E A, t}-\widehat{\alpha}_{E A} \Delta \bar{y}_{j, t}\right]+ \\
& +\left[\widehat{\beta}_{E A}\left(E_{t} \pi_{E A, t+k}-\bar{\pi}_{E A, t}\right)-\widehat{\beta}_{E A}\left(E_{t} \pi_{j, t+k}-\bar{\pi}_{j, t}\right)\right]+ \\
& +\left[\widehat{\gamma}_{E A}\left(E_{t} \Delta y_{E A, t+k}-\Delta \bar{y}_{E A, t}\right)-\widehat{\gamma}_{E A}\left(E_{t} \Delta y_{j, t+k}-\Delta \bar{y}_{j, t}\right)\right],
\end{aligned}
$$

where $\widehat{\alpha}_{E A}, \widehat{\beta}_{E A}$ and $\widehat{\gamma}_{E A}$ are the point estimates of the ECB reaction function.

In the above equation, the first two terms in brackets reflect what we label structural stress $\left(S_{j, t}^{s t r u c}\right)$, whereas the last two terms in brackets are related to cyclical stress $\left(S_{j, t}^{c y c}\right)$, i.e. to asynchronised short-run movements in inflation and growth expectations. Structural stress is defined as the difference between the estimated neutral interest rate for the euro area and the implied neutral interest rate for the country in question. As Equation (5) shows, we split up the neutral nominal interest rate in the neutral real interest rate (which is a function of the trend growth rate) and the inflation target. From this follows that the difference between the neutral nominal interest rate for the euro area and that for a specific country is due to both, a long-run inflation differential and a long-run growth differential.

\section{$2.3 \quad$ Limits}

It is quite evident that our counterfactual hinges on a range of assumptions, which require some more comments. In the counterfactual scenario a member country, which decides to leave the monetary union, sets its policy rate independently in an environment of flexible exchange rates by following the same policy rule as the ECB. The assumption that structural parameters are very similar across euro area countries implies that asynchronised business cycles can only be explained by asymmetries of (policy and non-policy) shocks across countries. A recent paper by Jondeau and Sahuc (2005) gives support to this assumption. Using a fully micro-founded and estimated multi-country model of the euro area, the paper reveals that structural differences in the behavior of private agents are not empirically relevant sources of business cycle heterogeneity across core countries of the euro area. They rather find that differences in actual business cycle developments are mainly due to similar types of shocks affecting the economies at different times. A similar conclusion is drawn by Giannone and Reichlin (2006).

The assumption that national central banks would implement a similar policy rule as the ECB - if they had the choice to do so-leads to a biased estimate of the true level of country-specific stress for most of the EMU 
member countries at least for two reasons. On the one hand, a strong motive for participating in the monetary union actually was (and still is) the move to a more independent and thereby more credible central bank. This did not only apply for most Southern European countries, which were in this way able to lower both their interest rates as well as their inflation rates substantially, but also for a country like Finland. The way we construct country-specific stress assumes that these countries would have been able to gain the same amount of credibility as the ECB, if they had decided to remain outside the EMU. However, and more realistically, a less credible national central bank would be forced to change policy rates more than a credible central bank (like the ECB) when confronted with the same shock. These higher reaction coefficients (i.e. $\beta_{j}>\beta_{E A}$ and $\gamma_{j}>\gamma_{E A}$ ) lead to - in absolute sense-larger country-specific stress levels. Hence, our stress estimates underestimates the true level of country-specific stress (credibility bias).

On the other hand, the counterfactual assumes that the national central bank reacts to growth and inflation expectations, which are conditional on the counterfactual interest rate policy. However, it is clear that the observed expectations are conditional on the current state of the economy, and by this on the impact of the factual interest rate policy of the ECB on the member country. To assess the resulting bias of our stress measure, let us suppose that the individual countries are hit by a sequence of non-policy shocks, which are independent of the monetary regime, and that these shocks are uncorrelated across countries. Let us further consider a country whose weight in the ECB's monetary policy decision process is clearly less than one, implying that country-specific movements in growth and inflation expectations are not fully taken into account. The factual interest rate policy of the ECB will only partly contribute to a stabilisation of macroeconomic developments in that country. As in the counterfactual scenario the national central bank's ultimate goal is to stabilise national cyclical movements in inflation and output, this would lead to more stability as compared to what we actually observe when the country participates in a monetary union. Hence, the counterfactual interest rate policy in the individual country with an independent monetary policy will normally be less pronounced and our stress measure will overestimate the true stress (stability bias).

Of course, an exact quantification of the two opposing biases would require a full-fledged multi-country dynamic stochastic general equilibrium model of the EMU, which is beyond the scope of the paper. A much simpler method to illustrate the uncertainty related to measuring stress in country $j$, is to view it as a random variable and to calculate confidence intervals using 
the sampling distribution of the estimators of the ECB Taylor rule:

$$
\begin{aligned}
\boldsymbol{S}_{\boldsymbol{j}, \boldsymbol{t}} & =\left[\bar{\pi}_{E A, t}-\bar{\pi}_{j, t}\right]+ \\
& +\left[\boldsymbol{\alpha}_{\boldsymbol{E} \boldsymbol{A}} \Delta \bar{y}_{E A, t}-\boldsymbol{\alpha}_{\boldsymbol{j}} \Delta \bar{y}_{j, t}\right]+ \\
& +\left[\boldsymbol{\beta}_{\boldsymbol{E} \boldsymbol{A}}\left(E_{t} \pi_{E A, t+k}-\bar{\pi}_{E A, t}\right)-\boldsymbol{\beta}_{\boldsymbol{j}}\left(E_{t} \pi_{j, t+k}-\bar{\pi}_{j, t}\right)\right]+ \\
& +\left[\boldsymbol{\gamma}_{\boldsymbol{E} \boldsymbol{A}}\left(E_{t} \Delta y_{E A, t+k}-\Delta \bar{y}_{E A, t}\right)-\boldsymbol{\gamma}_{\boldsymbol{j}}\left(E_{t} \Delta y_{j, t+k}-\Delta \bar{y}_{j, t}\right)\right] .
\end{aligned}
$$

In Equation (6) random variables are highlighted in bold. $\boldsymbol{\alpha}_{\boldsymbol{j}}, \boldsymbol{\beta}_{\boldsymbol{j}}$ and $\boldsymbol{\gamma}_{\boldsymbol{j}}$ have the same sampling distribution as the estimators for $\alpha_{E A}, \beta_{E A}$ and $\gamma_{E A}$, respectively. In the bootstrap they are, however, independently drawn from each other implying that country-specific reaction coefficients may deviate from the estimated ECB reaction coefficients, albeit only in a non-systematic way. It is clear that the resulting confidence intervals do not truly reflect the two biases described above, as they only account for the uncertainty resulting from the estimation of the ECB reaction coefficients. Notwithstanding this caveat, we use the upper (lower) confidence region to illustrate the credibility (stability) bias.

\section{Data}

To capture the forward-looking aspect of monetary policy, we take the expected growth and inflation rates from consensus forecasts as published on a monthly basis by Consensus Economics Inc. ${ }^{3}$ Every month, Consensus Economics Inc. surveys a large number of prominent financial and economic forecasters for their estimates of a range of variables including future growth, inflation, interest rates and exchange rates. Most industrialized countries in the world are covered and reference data are quickly disseminated. Forecasts are made for the current and the following year. The number of panelists ranges from 10 to 30 for each of the countries, and for the European countries the panelists are generally based in countries they forecast.

To our knowledge, only a handful of studies have used the consensus forecasts of Consensus Economics Inc. Among these studies Harvey et al. (2001), Loungani (2001) and Isiklar et al. (2006) contain formal tests of forecast efficiency. Although most studies agree that that there are some inefficiencies in the forecasts, it nevertheless appears difficult for individual institutes to outbeat the consensus forecast over prolonged periods of time.

\footnotetext{
${ }^{3}$ As Consensus Economics Inc. does not publish inflation and growth forecasts for Luxembourg, we are not able to include this country in our analysis. Given its GDP share of approximately 0.3 percent of euro area GDP, this will hardly affect the results. In a similar vein, it is not possible to carry out the analysis for the new EU member countries as data on GDP growth and inflation expectations back to 1999 are not available.
} 
Figure 1: 12-months ahead consensus forecasts of GDP growth and inflation for the euro area
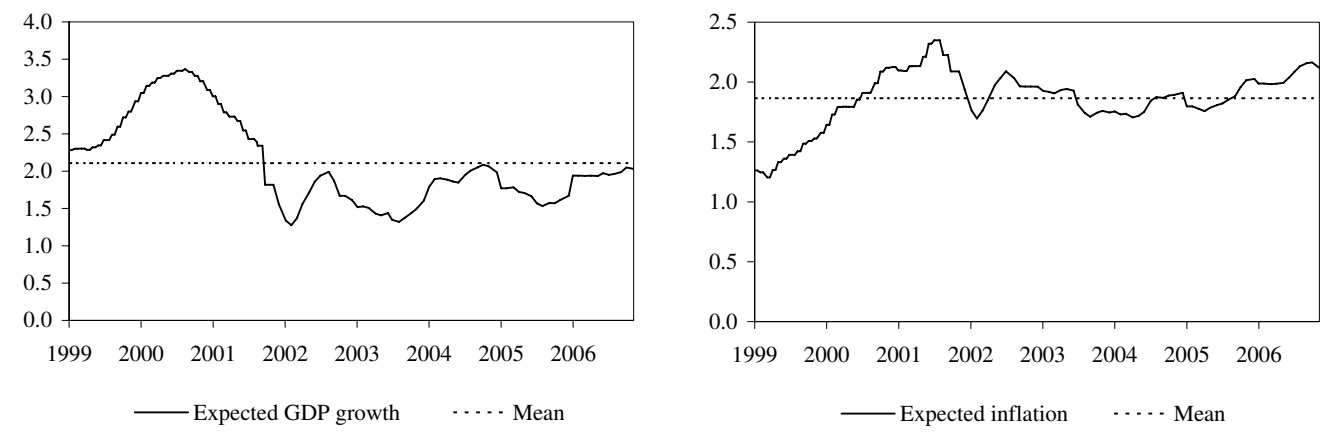

Source: Consensus Economics Inc.

Only in December 2002, Consensus Economics Inc. started publishing forecasts for the euro area. Hence, for our analysis - which starts at the introduction of the euro in 1999 - we are forced to aggregate the countryspecific survey results using GDP weights to the euro area. To be consistent we use this strategy for the entire sample period. As we will use the country-level data to construct country-specific stress indicators, this also ensures consistency in this respect. The correlation coefficient between our constructed euro area aggregates and the reported consensus results (for the sample since December 2002) are 0.93 and 0.98 for, respectively inflation and GDP growth.

To implement our theoretical framework presented in the previous Section, we need to make a number of assumptions. First, we will use the consensus forecasts (i.e. averages of the individual responses) of annual average real GDP growth and inflation for the upcoming 12 months, i.e. in the empirical analysis we will set $k=12$. Second, we assume the target inflation rates to be constant and proxy them by the expected inflation averages over the sample, i.e. $\bar{\pi}_{j, t}=\bar{\pi}_{j}=1 / T \sum_{t=t_{0}}^{T} E_{t} \pi_{j, t+k}$. Finally, trend growth is also approximated by its expected average over the sample: $\Delta \bar{y}_{j, t}=\Delta \bar{y}_{j}=1 / T \sum_{t=t_{0}}^{T} E_{t} \Delta y_{j, t+k} \cdot{ }^{4}$ Hence, we make the simplifying assumption that the trend growth rate is constant. While this is clearly at odds with the theoretical concepts developed inter alia by Woodford (2003), it might nevertheless be a good approximation for the relatively short time

\footnotetext{
${ }^{4}$ Alternatively, it would be possible to assume that either the neutral real interest rate or the inflation target is the same across all European countries. While the estimated ECB policy rule would not be affected by this, the cyclical stress measures would have a non-zero mean over the sample period and the interpretation of the two stress components would change. Overall stress would only be marginally affected.
} 
period we consider and avoids the use of filter techniques, which are difficult to apply on the relatively short sample defined by the operation period of the ECB. ${ }^{5}$ Figure 1 shows both time series for the euro area. ${ }^{6}$

We use data at the frequency of the ECB Governing Council meetings since 1999 and until the end of 2006 throughout the paper. There are some differences in the number of ECB Governing Council meetings during the years. Whereas in the 1999-2001 period there were two meetings each month, the Council only met once a month from 2002 on. As described by De Haan et al. (2005), the ECB has a range of instruments at its disposal for implementing monetary policy. To manage liquidity in the money market and steer short-term interest rates, it uses open market operations. The main refinancing operations are considered to be the most important and are executed as standard weekly tenders for liquidity-providing reverse transactions with a two-week maturity. We use the associated main refinancing rate as set at the Governing Council meetings as our proxy for monetary policy. ${ }^{7}$

\section{Empirical results}

\subsection{Taylor rule estimation}

In this Section we determine the reaction coefficients $\alpha_{E A}, \beta_{E A}$ and $\gamma_{E A}$, which are required to compute country-specific stress, by estimating the nested Taylor rule model that consists of Equations (1), (2) and (3). The estimation results are summarized in Table 1 . In accordance with most empirical studies on Taylor rules, the smoothing parameter $\rho_{E A}$ is positive and highly significant. Our estimates imply that each month the ECB only closes about 10 percent of the gap between the actual main refinancing rate and the desired interest rate level. However, we do not find any evidence of a positive serial correlation in the error term, which contrasts with the results obtained by Gorter et al. (2007). In fact our estimate for $\delta_{E A}$ is negative, which can be explained by the time series characteristics of our dependent variable. $^{8}$ For this reason and as the inclusion of serially correlated errors

\footnotetext{
${ }^{5}$ See for example Garnier and Wilhelmsen (2005) for the estimation of an unobserved components model with the Kalman filter using artificial euro area data from 1963 to 2004.

${ }^{6}$ Appendix B shows the country-specific time series.

${ }^{7}$ Note that the main refinancing rate usually moves synchronised with the two rates associated to the two standing facilities, the marginal lending or Lombard facility and the deposit facility. The standing facilities constitute a corridor for the (inter-bank) money market rate.

${ }^{8}$ While the main refinancing rate only exhibits 21 discrete changes over the sample period and is constant over the rest of the period, the changes in the three-month interbank
} 


\begin{tabular}{l|rr|r}
\hline \hline & \multicolumn{3}{|c}{ OLS } \\
\hline Interest rate smoothing $\left(\rho_{E A}\right)$ & $0.91^{* *}$ & $0.90^{* *}$ & $0.90^{* *}$ \\
& $(0.02)$ & $(0.03)$ & $(0.03)$ \\
Neutral real rate $\left(\alpha_{E A}\right)$ & $0.50^{* *}$ & $0.50^{* *}$ & $0.50^{* *}$ \\
& $(0.06)$ & $(0.06)$ & $(0.06)$ \\
Inflation expectations $\left(\beta_{E A}\right)$ & $1.63^{* *}$ & $1.63^{* *}$ & $1.65^{* *}$ \\
& $(0.44)$ & $(0.43)$ & $(0.42)$ \\
Expected output growth $\left(\gamma_{E A}\right)$ & $1.56^{* *}$ & $1.52^{* *}$ & $1.51^{* *}$ \\
& $(0.18)$ & $(0.17)$ & $(0.17)$ \\
Serially correlated error $\left(\delta_{E A}\right)$ & $-0.14^{* *}$ & - & - \\
& $(0.04)$ & & \\
\hline Cragg-Donald statistic & - & - & 1070.3 \\
Hausman p-value & - & - & 0.9983 \\
Quandt-Andrews p-value & - & 0.2984 & - \\
\hline \hline
\end{tabular}

Notes: Heteroscedasticity and autocorrelation consistent standard errors shown in parentheses. ${ }^{*}$ denotes significance at $10 \%$, and ${ }^{* *}$ significance at $5 \%$. The instruments of the IV regression are: $i_{E A, t-2}, E_{t-1} \pi_{E A,(t-1)+12}$, $E_{t-2} \pi_{E A,(t-2)+12}, \quad E_{t-1} \Delta y_{E A,(t-1)+12}, \quad E_{t-2} \Delta y_{E A,(t-2)+12} . \quad$ The critical value of the Cragg-Donald statistic is a function of the number of potentially endogenous regressors $(n)$, the number of instruments $\left(K_{2}\right)$ and the desired maximal bias of the IV estimator relative to OLS $(b)$. For a significance level of $5 \%, n=2, K_{2}=5$ and $b=0.05$ the critical value is 13.97 .

Table 1: Estimation results for the euro area Taylor rule, 1999-2006

has no significant impact on the estimates of the remaining parameters, we decided for the Taylor rule model without serial correlation (i.e. the second column in Table 1) as our benchmark specification.

The reaction coefficients $\alpha_{E A}, \beta_{E A}$ and $\gamma_{E A}$ are all statistically significant and show the expected positive signs. The estimate for $\alpha_{E A}$ suggests that the neutral real interest rate is equal to one half of the trend growth rate of real GDP. Given a mean of expected GDP growth over the sample period of 2.1 percent and a mean of expected inflation of 1.9 percent (see Figure 1), the estimated nominal and real neutral rates are about 3 percent and 1.1 percent, respectively. While the value for the nominal neutral rate simply reflects the average nominal refinancing rate over the 1999-2006 period, it is much lower than the estimates obtained in studies using a longer sample. Garnier and Wilhelmsen (2005) who also assume a linear relationship between the neutral real rate and the trend growth rate of GDP, report an estimate for $\alpha_{E A}$ of

rate, which is used by Gorter et al. (2007) as dependent variable, are more continuous. Below in Table 2 we will confirm the results by Gorter et al. (2007) and show that a positive serial correlation in the error term can be obtained by using the Euribor threemonth interbank rate as dependent variable. 
around 0.9 , which implies a neutral real and nominal rate of 3.8 percent and 1.9 percent, respectively.

The coefficient $\beta_{E A}$ measures the response of the ECB to changes in inflation expectations. If inflation expectations rise by 1 percentage point, the ECB will raise its target rate by 1.63 percentage points. Thus, the interest rate policy of the ECB is stabilizing as it clearly fulfills the Taylor principle, which says that real interest rates should increase following a rise in (expected) inflation. Studies like Gerdesmeier and Roffia (2004), Surico (2003), as well as Ullrich (2003), which use realised inflation and output data, estimated small reactions to inflation movements and thereby have suggested a destabilising role of the ECB. As noted by Sauer and Sturm (2003, 2007) and more recently by Castelnuovo (2007) and Gorter et al. (2007), this can largely be attributed to the use of backward-looking as compared to forwardlooking specifications. ${ }^{9}$ Hence, more recent papers focusing on the euro area, like Fendel and Frenkel (2005, 2006) and Hayo and Hofmann (2006), specify Taylor rules in a forward-looking manner. These more recent studies report coefficient estimates for $\beta_{E A}$ between 1.5 and 2.0.

The positive and highly significant coefficient of the expected output gap $\gamma_{E A}$ implies that above average growth indeed leads to higher interest rates. This is perfectly in line with previous literature. Our coefficient estimates suggest that the ECB takes movements in real variables at least as serious as movements in inflation.

In addition to the coefficient estimates, Table 1 reports the p-value of the Quandt-Andrews structural change test. As the null hypothesis that there are no breakpoints within trimmed data cannot be rejected at conventional levels, the OLS regression is unlikely to suffer from instability. ${ }^{10}$

Another potential problem, which arises when expectations for inflation and GDP growth are made under the assumption that the policy rate will not be constant within the forecasting horizon, is that the OLS regression

\footnotetext{
${ }^{9}$ As compared to the US, where Orphanides (2001) has shown that estimated policy reaction functions obtained using the ex-post revised data can yield misleading descriptions of historical policy, the use of real-time data appears to be of minor influence. Nevertheless, by using consensus forecasts also this real-time aspect is directly dealt with in this paper.

${ }^{10}$ The Quandt-Andrews breakpoint test tests for one, or more, unknown structural breakpoints in an equation's sample. The basic idea behind the Quandt-Andrews test is that a single Chow breakpoint test is performed at every observation between two dates $\tau_{1}$ and $\tau_{2}$. The $k$ test statistics from those Chow tests are then summarized into one test statistic for a test against the null hypothesis of no breakpoints between $\tau_{1}$ and $\tau_{2}$. As the distribution of the statistics becomes degenerate as $\tau_{1}$ approaches the beginning of the equation sample, or $\tau_{2}$ approaches the end of the equation sample, it is typical to exclude the first and the last 7.5 percent of the observations, leading to 15 percent trimming of the sample.
} 
Figure 2: Taylor rule estimation
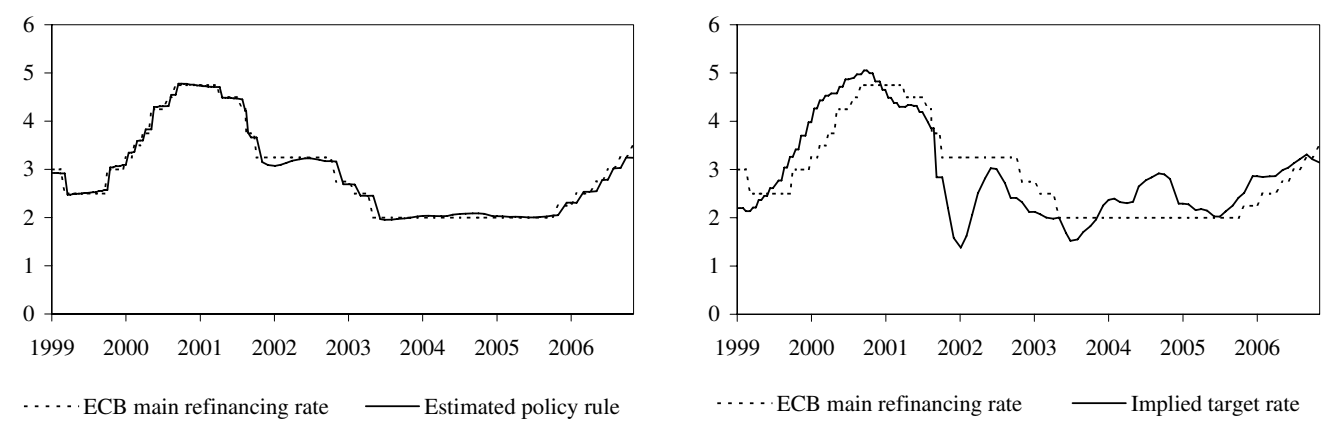

may be subject to endogeneity of the regressors. ${ }^{11}$ This would cause the estimates to be inconsistent. To test for the exogeneity of our right-handside variables, we run a Hausman test. The final column of Table 1 shows the IV estimators of a 2SLS regression. As instruments for expectations we use the first and the second lag of the explanatory variables. ${ }^{12}$ The Hausman test compares the estimated coefficients of the IV and OLS regressions in the last two columns of Table 1. The null hypothesis that the OLS estimator yields consistent and efficient estimates cannot be rejected at conventional levels. Hence, we can safely conclude that endogeneity of neither inflation nor growth expectations is empirically an issue.

The fit of our baseline specification is illustrated in Figure 2. It shows the modified Taylor rule rate with and without interest smoothing. Except for the winter of $2001 / 2002$, in which both growth and inflation expectations plummeted but the ECB did not further lower its interest rates, the estimated modified Taylor rule appears to lead actual ECB interest rate decisions quite well. If the Taylor rate lies above the ECB main refinancing rate, then an interest rate increase is more likely to happen than a decrease. The reverse holds for Taylor rates below the actual ECB interest rate.

To further check the robustness of our baseline forward-looking Taylor rule specifications, we experiment with alternative expectation and policy rate measures. First, we replace the main refinancing rate as a proxy for the

\footnotetext{
${ }^{11}$ Note, though, that as we know when each observations of each of time series has been published, we are certain that all information listed on the right-hand side of our nested equation is publicly available before each interest rate decisions is actually made.

${ }^{12}$ Table 1 reports the Cragg and Donald (1993) statistic, which is the smallest eigenvalue of the matrix analog of the F-statistic from the first-stage regression. The null hypothesis that the instruments are weak is rejected if the Cragg-Donald statistic exceeds the critical value. The critical values are presented by Stock and Yogo (2005). The test strongly rejects the null hypothesis of weak instruments.
} 
Figure 3: Robustness of the Taylor rule estimation
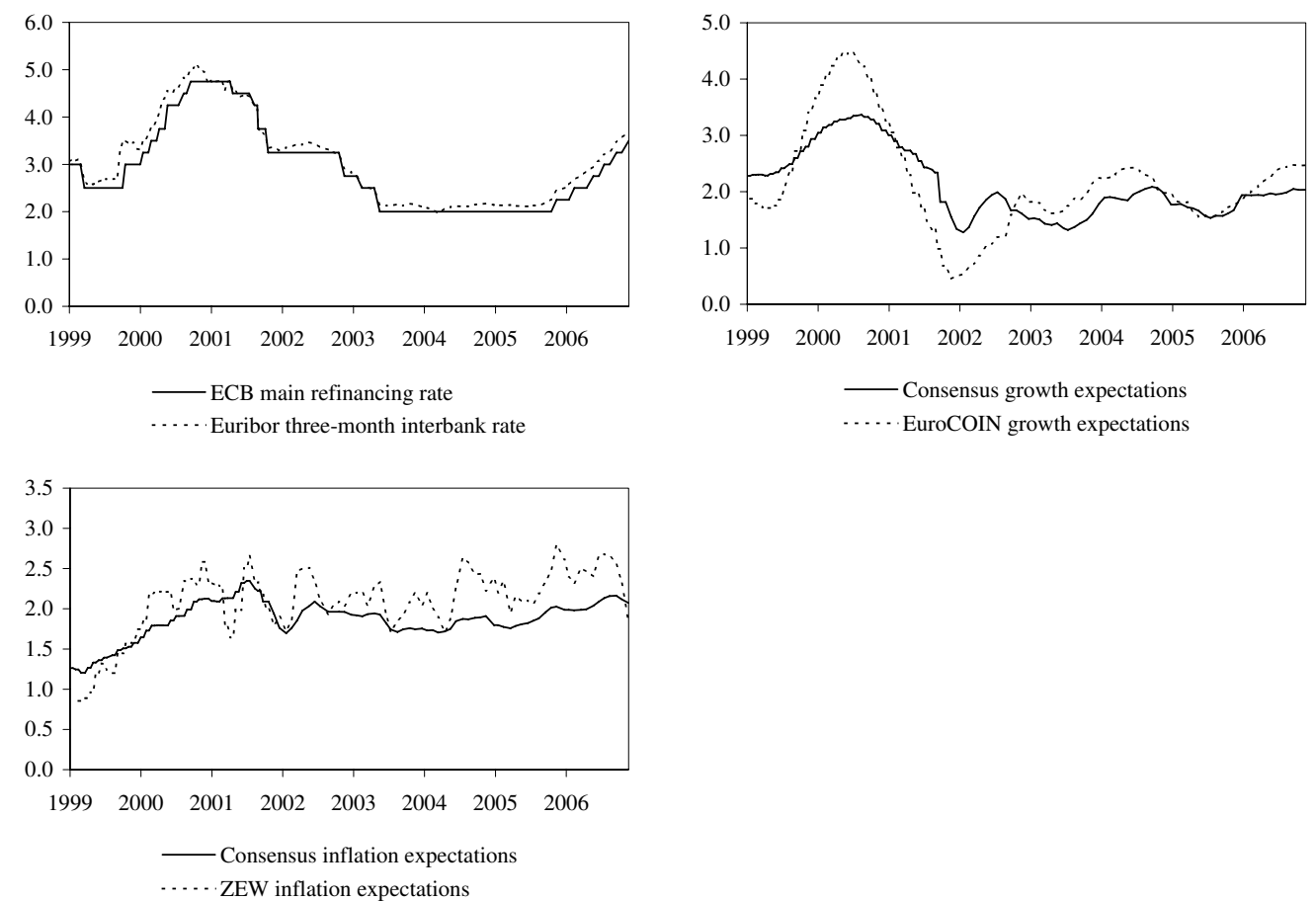

Source: ECB, CEPR, ZEW, Consensus Economics Inc.

policy rate by the ECB's operating target, the Euribor three-month interbank rate. Then we take as an alternative source for GDP growth expectations the EuroCOIN indicator. This indicator is published by the Centre for Economic Policy Research (CEPR) and provides an estimate of the monthly growth rate of euro area GDP. Finally, with respect to inflation, the Germany-based Centre for European Economic Research (ZEW) queries 6-months-ahead euro area inflation expectations among German financial markets experts. As the ZEW data is qualitative, it is converted into quantitative measures of inflation expectations using the probability approach pioneered by Carlson and Parkin (1975) and adapted for the ZEW data by Heinemann and Ullrich (2006). ${ }^{13}$ As shown by Figure 3 especially the alternative expectation measures do vary across the different data sources.

Table 2 shows the Taylor rule coefficients when these alternative data sources are used one at a time. The main results can be summarized as follows. Interest rate smoothing is an important and significant element of the ECB's monetary policy strategy, irrespective of the data used for proxying

${ }^{13}$ Appendix A briefly explains the procedure of Heinemann and Ullrich (2006). 


\begin{tabular}{l|cc|r|r}
\hline \hline & \multicolumn{2}{|c}{ Euribor } & \multicolumn{1}{c}{ EuroCOIN } & ZEW \\
\hline Interest rate smoothing $\left(\rho_{E A}\right)$ & $0.92^{* *}$ & $0.91^{* *}$ & $0.96^{* *}$ & $0.93^{* *}$ \\
& $(0.03)$ & $(0.03)$ & $(0.01)$ & $(0.02)$ \\
Neutral real rate $\left(\alpha_{E A}\right)$ & $0.58^{* *}$ & $0.58^{* *}$ & $0.52^{* *}$ & $0.40^{* *}$ \\
& $(0.08)$ & $(0.08)$ & $(0.13)$ & $(0.08)$ \\
Inflation expectations $\left(\beta_{E A}\right)$ & $1.17^{*}$ & $1.17^{*}$ & $1.69^{* *}$ & $1.09^{* *}$ \\
& $(0.66)$ & $(0.67)$ & $(0.84)$ & $(0.33)$ \\
Expected output growth $\left(\gamma_{E A}\right)$ & $1.58^{* *}$ & $1.50^{* *}$ & $1.36^{* *}$ & $1.77^{* *}$ \\
& $(0.23)$ & $(0.23)$ & $(0.34)$ & $(0.23)$ \\
Serially correlated error $\left(\delta_{E A}\right)$ & - & $0.23^{* *}$ & - & - \\
& & $(0.08)$ & & - \\
\hline \hline
\end{tabular}

Notes: Heteroscedasticity and autocorrelation consistent standard errors shown in parentheses. ${ }^{*}$ denotes significance at $10 \%$, and ${ }^{* *}$ significance at $5 \%$.

Table 2: Robustness of the Taylor rule estimation

inflation and growth expectations. When we use the Euribor three-month interbank rate as dependent variable, the serial correlation model is confirmed, without having any significant impact on the remaining reaction coefficients. The various estimates for $\alpha_{E A}, \beta_{E A}$ and $\gamma_{E A}$ show that our baseline estimates represent a good "mean" of the ECB's reaction coefficients. In all three cases, the Taylor principle is fulfilled. Moreover, the $95 \%$ confidence bands of the point estimates in Table 2 overlap with those of our preferred forward-looking Taylor rule specifications in Table 1. Thus, we conclude that our baseline estimates are very robust against the use of alternative proxies for expectations and the policy rate.

\subsection{The counterfactual scenario}

Before we proceed to the calculation of stress for the individual member countries and the euro area as a whole, we present some empirical support for the assumption of our counterfactual scenario that the national central banks would implement a similar policy rule as the ECB - if they had the choice to do so. For this purpose we estimate Taylor rules for countries, which are not part of the EMU and whose monetary policy strategy is akin to that of the ECB. We decided for four (Western) European countries (Denmark, Sweden, Switzerland and the UK), in which in the past there has already been a debate about EMU accession.

For the estimation of the Taylor rules we use the most general model specification with Consensus expectations and a lagged dependent variable as explanatory variables and a serially correlated error. The dependent variable is the monthly average of the three-month interbank rate. As for the ECB 


\begin{tabular}{|c|c|c|c|c|}
\hline & Denmark & Sweden & Switzerland & $\overline{\mathrm{UK}}$ \\
\hline Interest rate smoothing $\left(\rho_{j}\right)$ & $\begin{array}{r}0.93^{* *} \\
(0.03)\end{array}$ & $\begin{array}{r}0.93^{* *} \\
(0.02)\end{array}$ & $\begin{array}{r}0.89^{* *} \\
(0.03)\end{array}$ & $\begin{array}{r}0.96^{* *} \\
(0.02)\end{array}$ \\
\hline Neutral real rate $\left(\alpha_{j}\right)$ & $\begin{array}{r}0.63^{* *} \\
(0.17)\end{array}$ & $\begin{array}{r}0.56^{* *} \\
(0.11)\end{array}$ & $\begin{array}{r}0.28^{* *} \\
(0.11)\end{array}$ & $\begin{array}{r}1.01^{* *} \\
(0.22)\end{array}$ \\
\hline Inflation expectations $\left(\beta_{j}\right)$ & $\begin{array}{r}3.99^{* *} \\
(1.48)\end{array}$ & $\begin{array}{r}1.89^{* *} \\
(0.59)\end{array}$ & $\begin{array}{r}1.64^{* *} \\
(0.66)\end{array}$ & $\begin{array}{l}2.31 \\
(3.54)\end{array}$ \\
\hline Expected output growth $\left(\gamma_{j}\right)$ & $\begin{array}{r}2.77^{*} \\
(1.68)\end{array}$ & $\begin{array}{r}1.48^{* *} \\
(0.70)\end{array}$ & $\begin{array}{r}1.56^{* *} \\
(0.51)\end{array}$ & $\begin{array}{l}2.64 \\
(1.67)\end{array}$ \\
\hline Serially correlated error $\left(\delta_{j}\right)$ & $\begin{array}{l}0.28 \\
(0.20)\end{array}$ & $\begin{array}{r}0.40^{* *} \\
(0.13)\end{array}$ & $\begin{array}{l}0.21 \\
(0.14)\end{array}$ & $\begin{array}{r}0.35^{* *} \\
(0.18)\end{array}$ \\
\hline
\end{tabular}

Notes: Heteroscedasticity and autocorrelation consistent standard errors shown in parentheses. ${ }^{*}$ denotes significance at $10 \%$, and ${ }^{* *}$ significance at $5 \%$.

Table 3: Estimation results for the Taylor rule in non-EMU countries, 19992006

Taylor rule the sample period goes from 1999 to 2006 .

The results, which are summarised in Table 3, show that - except for the UK - the modified Taylor rule specification is a good description of recent monetary policy in these countries. The central banks react positively to expected deviations of inflation and output growth from target rates, interest rate smoothing plays an important role, the neutral real interest rates are pinned down by trend growth rates, and serial correlation in the error term is significant for Sweden and the UK. Most importantly, however, the results seem to confirm the credibility bias that has been elaborated in Section 2.3: the estimates of the reaction coefficients $\beta_{j}$ and $\gamma_{j}$ are generally larger than those obtained in the baseline estimation of the ECB policy rule.

In addition to that, the four non-EMU countries also provide some evidence for the stability bias. Table 4 shows that both, the variance of inflation expectations and the variance of expected output growth, are generally smaller than the average variances over all EMU countries. Thus, countryspecific monetary policy seems to stabilise expectations more than area-wide policy.

\subsection{Stress from a country perspective}

For the calculation of country-specific stress we use the point estimates of the Taylor rule parameters $\alpha_{E A}, \beta_{E A}$ and $\gamma_{E A}$ of the baseline regression (second column in Table 1) together with the country-specific consensus forecasts. Then using Equation (6) allows us to create Figure 4. The solid lines represent the case where country-specific reaction coefficients and ECB reaction 


\begin{tabular}{l|c|c}
\hline \hline & $\operatorname{Var}\left[E_{t} \pi_{j, t+12}\right]$ & $\operatorname{Var}\left[E_{t} \Delta y_{j, t+12}\right]$ \\
\hline Denmark & 0.27 & 0.27 \\
Sweden & 0.52 & 0.64 \\
Switzerland & 0.31 & 0.46 \\
UK & 0.17 & 0.49 \\
\hline average over EMU countries & 0.38 & 0.68 \\
\hline \hline
\end{tabular}

Table 4: Variance of inflation and output growth expectations, 1999-2006

coefficients are identical. The confidence intervals are calculated as the 0.025 and 0.975 quantiles of the sampling distribution obtained from a bootstrap procedure with 1,000 replications. In each replication of the bootstrap procedure the reaction coefficients are independently drawn from the sampling distribution, so that $\alpha_{j}, \beta_{j}$ and $\gamma_{j}$ may deviate randomly from $\alpha_{E A}, \beta_{E A}$ and $\gamma_{E A}$, respectively.

The figure highlights that in countries like Greece, Ireland, Portugal and Spain, stress has been negative for most of the EMU period. This implies that if, for example, the ECB had conducted monetary policy for Ireland alone, it would have set nominal interest rates almost 7 percentage points higher at the end of 2000. At the other extreme end is Germany, where stress has always been positive. There, the interest rate would for instance have been 1.6 percentage points lower in mid-2003. Overall the actual monetary policy of the ECB seems to have been relatively appropriate for countries like Belgium and Italy. In those countries the average stress levels were close to zero and only showed moderate fluctuations. Also in the Netherlands and Finland average stress levels were close to zero. Here, however, clearly more pronounced cyclical patterns are visible. Stress levels in the Netherlands, for instance, ranged from -3 percent to 1.9 percent.

Figures 5 to 7 show the decomposition of country-specific stress related to differences in inflation and growth expectations into its cyclical and structural components (see Equation (5) for details on the decomposition). As by construction average cyclical stress in each country is zero, the sum of both components of structural stress accounts for the average overall stress. Especially Greece, Ireland, Portugal and Spain have experienced negative structural stress levels. As shown by Figure 5, this is to a large part explained by relative high average inflation expectations in those countries. Only for Ireland above average growth expectations played a more important role. In most of the remaining countries structural stress related to differences in growth and inflation expectations either was close to zero or compensated each other so that overall structural stress was close to zero. 
Figure 4: Country-specific stress
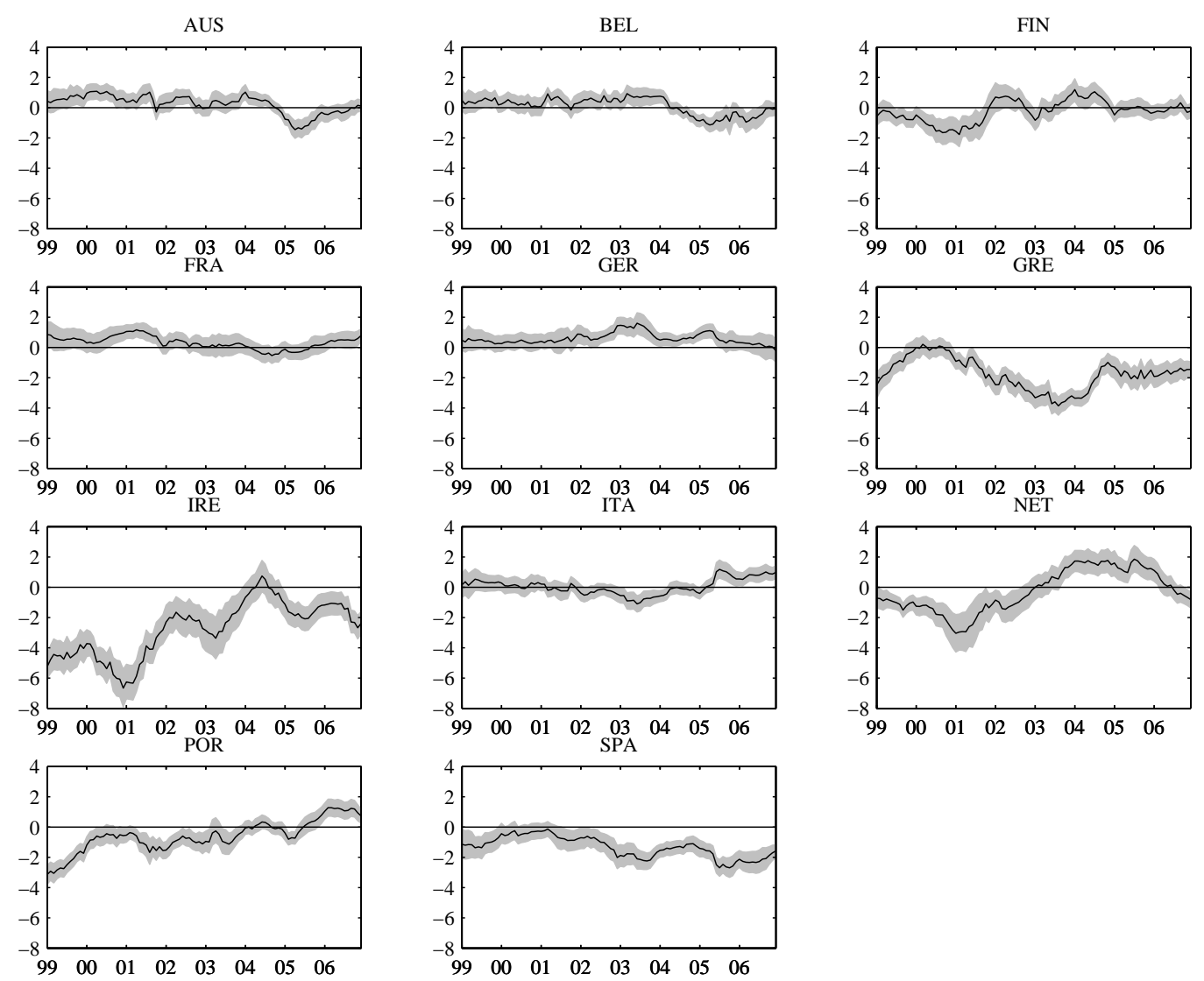

Notes: The shaded areas are 95 percent confidence intervals, which are calculated as the 0.025 and 0.975 quantiles of the sampling distribution obtained from a bootstrap procedure with 1,000 replications.

A notable exception is Germany where structural stress was highest due to both, low average inflation expectations and low average growth expectations. Put into numbers, if the ECB had conducted monetary policy for Germany alone, the neutral nominal interest rate, and hence the average interest rate over the 1999-2006 period, would have been 0.6 percentage points below its actual level.

Ireland not only had the highest (absolute) level of structural stress, but also its cyclical stress was more pronounced than in other countries. This is explained by both a more pronounced growth and inflation cycle in Ireland than elsewhere and a different timing of the cycle (see Figures 6 and 7). Also in the Netherlands cyclical fluctuations in inflation were, on average, rather strong during the past eight years, with inflation expectations above 3.5 per- 
Figure 5: Structural stress

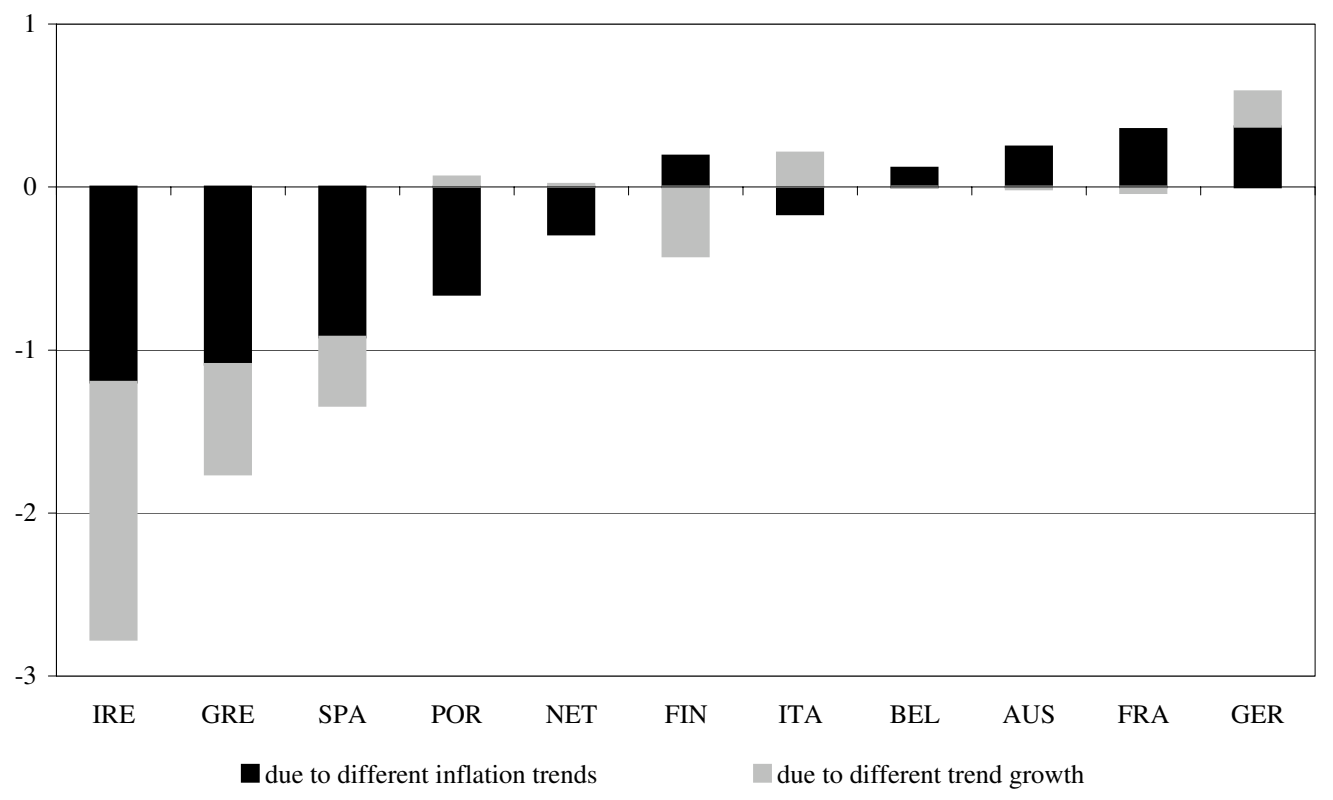

cent during the first half of 2006 and expectations as low as 1.25 percent in 2005. These cyclical misalignments in inflation expectations alone would have warranted a 2.0 percentage point higher main refinancing rate for the Netherlands in the second quarter of 2001 and a 1.5 percentage point lower one at the beginning of 2005. Cyclical stress in Germany, on the other hand, has been relatively low overall. Only the year 2003, in which inflation expectations in Germany fell significantly, stands out in this cyclical perspective; combined also with cyclically low growth, the main refinancing rate should have been almost 1.0 percentage points lower from a purely German perspective in the third quarter of 2003. Combined with the above-mentioned structural stress, this would imply a main refinancing rate of only 0.4 percent instead of the actual rate of 2.0 percent.

\subsection{Stress from a European perspective}

By aggregating the stress indicators to a euro area level and analysing their developments over time, our framework allows to construct useful measures of synchronisation tendencies within the euro area. For this purpose we first have to find an appropriate weighting scheme. From a positive point of view, the primary objective of the ECB is price stability. This has been defined by its Governing Council to imply a year-on-year increase of the Harmonised 
Figure 6: Stress due to asynchronised inflation cycles
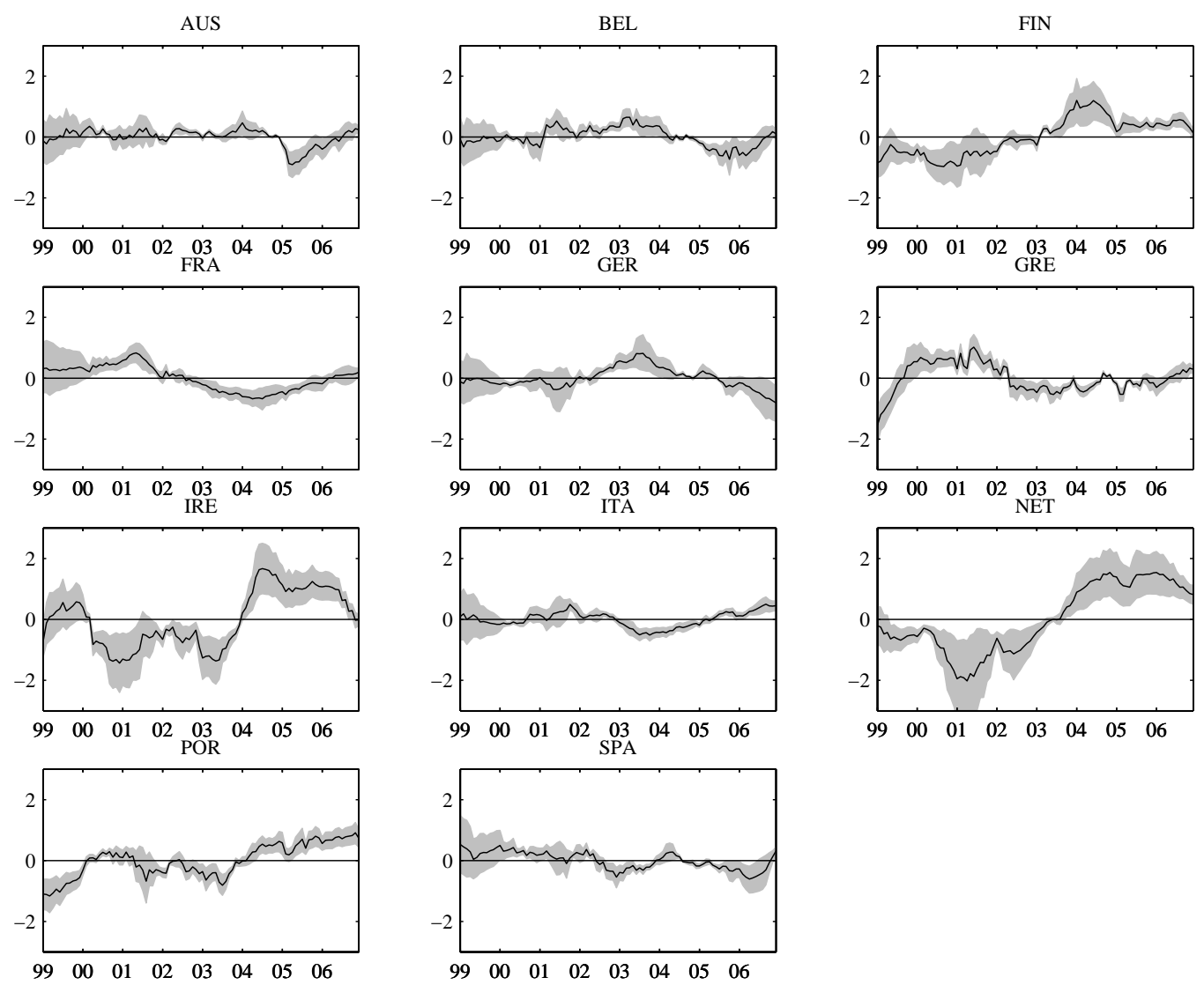

Notes: The shaded areas are 95 percent confidence intervals, which are calculated as the 0.025 and 0.975 quantiles of the sampling distribution obtained from a bootstrap procedure with 1,000 replications.

Index of Consumer Prices (HICP) for the euro area, which does not exceed 2 percent in the medium term. The euro area HICP is a GDP-weighted average of the country-specific harmonised consumer price indices. ${ }^{14}$ Hence, if we assume that decision making in the ECB Governing Council always results in policy decisions which maximise the welfare of the whole monetary union, i.e. the members of the council take a truly euro area perspective, we

\footnotetext{
${ }^{14}$ To be precise, the country weights calculated by Eurostat are derived from national accounts data for household final monetary consumption expenditure. A comparison between the average Eurostat weights and the average GDP shares over the 1999-2006 period shows that discrepancies between the two weights are very small.
} 
Figure 7: Stress due to asynchronised growth cycles
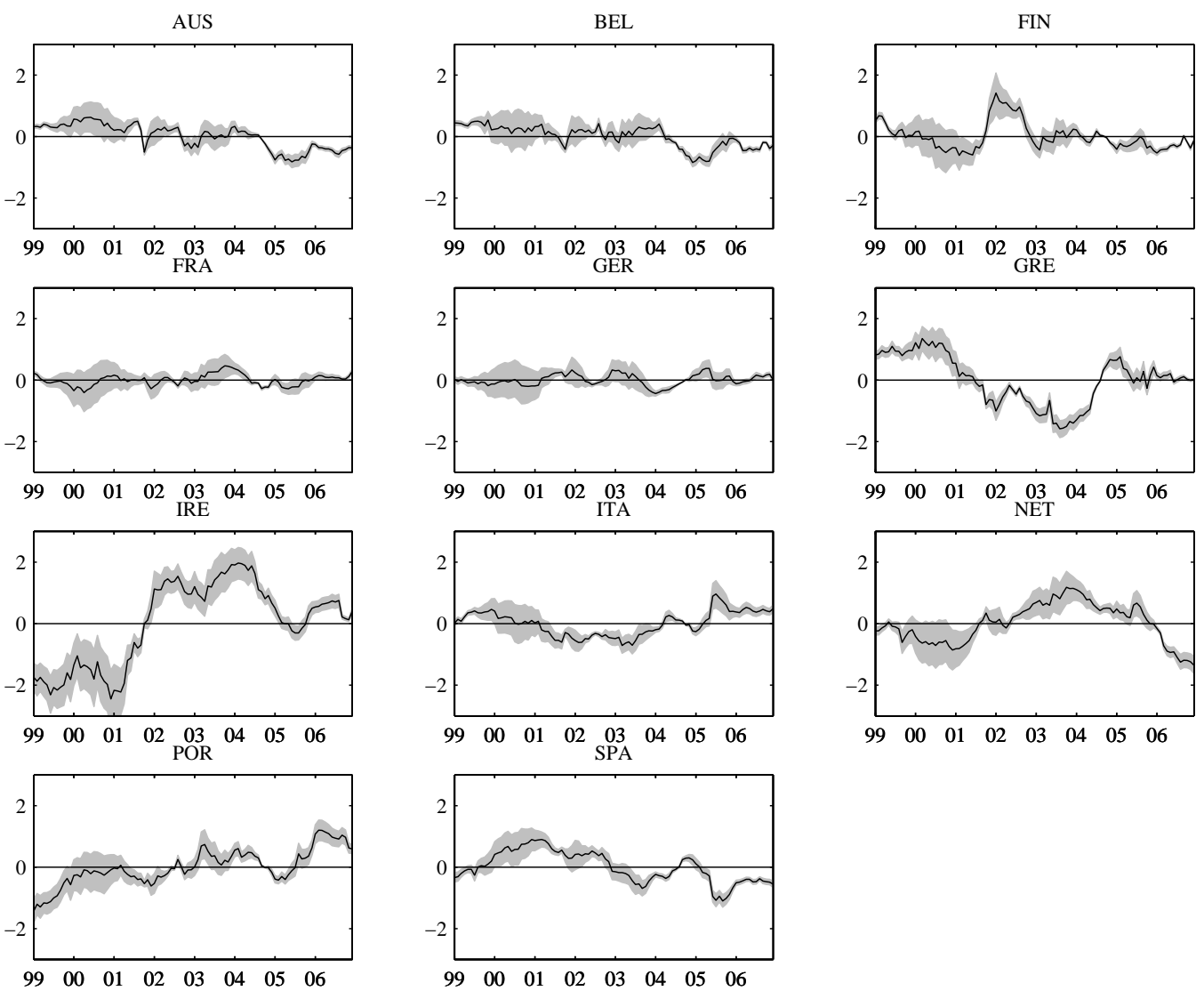

Notes: The shaded areas are 95 percent confidence intervals, which are calculated as the 0.025 and 0.975 quantiles of the sampling distribution obtained from a bootstrap procedure with 1,000 replications.

should use GDP shares to weigh the individual country stress levels as well. ${ }^{15}$ To be able to aggregate stress indicators to the euro area, we furthermore neglect the sign of the stress level at a country level. ${ }^{16}$ Hence, we make the simplifying assumption that too high and too low interest rates are causing stress to an equal degree. Hence, we compute aggregate stress in the euro area as a GDP weighted average of absolute country-specific stress levels: $S_{E A, t}^{a b s}=\sum_{j} w_{j}\left|S_{j, t}\right|$, where $w_{j}$ is the weight attributed to country $j$.

On average, aggregate absolute stress equals 0.71 percentage points. Stress levels are, however, not constant over time. Figure 8 shows how overall stress

\footnotetext{
${ }^{15}$ The use of GDP shares is also consistent with the way we constructed area-wide aggregates of the national expectation series.

${ }^{16}$ By construction, euro area stress would otherwise always equal zero.
} 
Figure 8: Weighted absolute sum of stress in the euro area
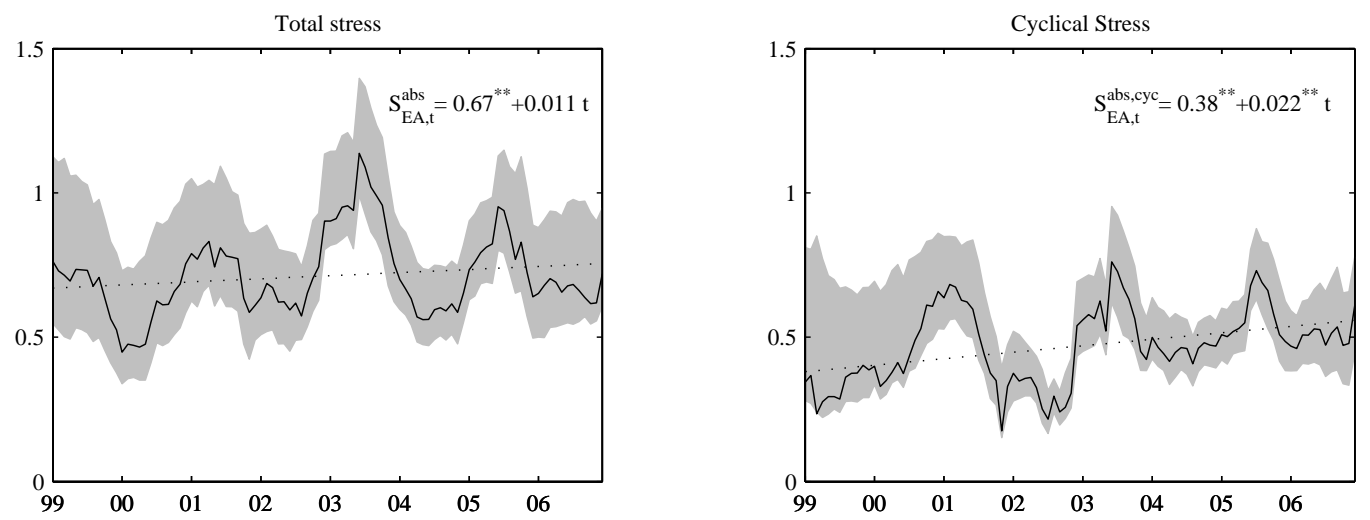

Notes: The shaded area are the 95 percent confidence interval, which are calculated as the 0.025 and 0.975 quantile of the sampling distribution obtained from a bootstrap procedure with 1,000 replications. As the distribution of country-specific absolute stress is truncated at zero and hence skewed to the right, the confidence intervals around the means (which are computed using the point estimates of the baseline Taylor rule regression) are asymmetric. The dotted lines are linear trends of the means, whose estimated intercepts and (annualised) slopes are indicated in each graph. ${ }^{*}$ denotes significance at $10 \%$, and ${ }^{* *}$ significance at $5 \%$.

has evolved. In particular, during 2003 and in the summer of 2005 stress levels were relatively high in the euro area, indicating large business cycle asymmetries across euro area countries. On the other hand, there are periods where stress levels clearly fell, indicating that a common shock hit the euro area. For instance, the common shock due to September 11, 2001 allowed the ECB to reduce stress in all member countries at the same time.

Figure 8 also shows that overall euro area stress does not show a downward trend over time; if anything there is a slight - but insignificant - upward trend. Focusing on cyclical stress only $\left(S_{E A, t}^{a b s, c y c}=\sum_{j} w_{j}\left|S_{j, t}^{c y c}\right|\right)$, the positive trend even becomes significant. For a correct interpretation, it must be emphasised that trends in total stress are exclusively determined by cyclical stress, whereas structural stress only contributes to the average level of total stress. Hence, this result does not suggest that the degree of business cycle synchronisation has steadily increased during the past eight years. This speaks against the argument that the introduction of a monetary union automatically reduces differences in cyclical developments among its member countries. 


\subsection{Discussion of the results}

\subsubsection{Structural stress and the real exchange rate channel}

At least on a euro area level, stress is quite persistent over our eight year sample. The finding that stress is not decreasing over time in the euro area as a whole is, in many eyes, a very unsatisfactory result. In particular the fact that in most of the euro area countries interest rates are systematically too low or too high over such a long period of time must raise the question whether stress is not reinforcing itself. By focussing on the interest rate alone when calculating monetary stress, we so far ignored an important adjustment mechanism that operates within a monetary union. According to the real exchange rate channel, inflation differentials between countries in the monetary union lead to changes in the relative price competitiveness among these countries, and hence to changes of the real exchange rate of euro area member countries relative to their euro area trading partners. When, for example, in countries with high structural inflation (which for most countries in our sample goes along with a higher trend growth rate of GDP relative to the EMU average) ECB policy rates are too expansive on average (i.e. stress is negative), an appreciating real exchange rate may, to a certain degree, compensate for this. An important feature of the real exchange rate channel are its accumulative dynamics. The longer structural inflation differentials persist, the more the relative price competitiveness improves or deteriorates and the more the real exchange rate channel compensates (or even overcompensates) the interest rate channel (irrespective of the elasticities of GDP and inflation with respect to the interest rate and the exchange rate).

To avoid the problems related to the estimation of open economy Taylor rules (see e.g. Fourçans and Vranceanu, 2004, and Carstensen and Colavecchio, 2006 for attempts to take into account exchange rate movements in an ECB Taylor rule), we address the exchange rate issue in a rather qualitative fashion. Figure 9 depicts the average real appreciation of a country vis-à-vis the rest of the euro area (measured as the average annualized change of the real exchange rate over the previous month in percent) against the structural inflation stress (in percentage points). The scatter plot, in which the dots all lie very close to a falling $45^{\circ}$-line, suggests that structural inflation stress is compensated almost one-to-one by a change in the real exchange rate. If, for example, inflation in one country was on average over the 1999-2006 one percentage point higher than in the euro area as a whole (implying a negative stress in this country), the real exchange rate appreciates by about one percent per annum. This appreciation of the currency vis-à-vis the rest of the euro area counteracts the on average expansive monetary policy stance 
Figure 9: The compensating role of the real exchange rate



Notes: $\Delta \bar{q}_{j}$ : average annualized change of the real exchange rate of country $j$ vis-àvis the rest of the euro area over the previous month in percent (increase indicates real appreciation); $\bar{\pi}_{E A}-\bar{\pi}_{j}$ : difference between the average expected inflation in the euro area and the average expected inflation in country $j$ in percentage points (structural inflation stress). Heteroscedasticity and autocorrelation consistent standard errors shown in parentheses. ${ }^{*}$ denotes significance at $10 \%$, and ${ }^{* *}$ significance at $5 \%$.

due the on average higher inflation rate.

In addition, the direct effect of the change in the real exchange rate is complemented by a drift of the real exchange rate away from its initial level, which is increasing in time. For the country in the above example this implies that, after eight years, the level of the real exchange rate is (roughly) $8 \%$ higher than at the beginning of EMU. The extent to which this appreciation of the real exchange rate has a contractionary impact on the country crucially depends on the level of the equilibrium real exchange rate. If the real exchange rate was at its equilibrium at the beginning of EMU, the increase of the real exchange rate was indeed compensating for the negative monetary stress. If, by contrast, the exchange rate of the country was undervalued by, say, $8 \%$ in real terms at the beginning of EMU, the increase in the real exchange rate only implies a reduction of the stimulating relative price advantages.

Due to this time dependency of the change in the relative price competitiveness, the impact of the real exchange rate channel on total stress would increase over time, irrespective of the response coefficient in an augmented 
Taylor rule. As a general rule, the longer structural inflation differences persist, the more the related drift of the level of the real exchange rate would compensate for this type of structural stress.

\subsubsection{Cyclical stress and the weighting of member countries in the monetary policy decision process}

Not only the result that (cyclical) stress at the euro area level is increasing rather than decreasing over time, but also the contribution of each member country to total stress requires some further discussion. In this Section we assume that the ECB takes structural differences across member countries as given and has a focus on stabilising cyclical movements. ${ }^{17}$ So far, we have modeled a decision process within the ECB in which the decision makers act fully in the interest of the euro area as a whole and have therefore used GDP shares for the aggregation of national to area-wide data. The country decomposition of absolute cyclical stress in Table 5 shows that in the case of GDP weights the cyclical component of aggregate euro area stress has been very unevenly distributed across EMU member countries. Especially the large countries, and in particular Germany, have much higher weighted absolute cyclical stress levels and therefore implicitly have received a lower political weight than suggested by their economic share in euro area GDP. Hence, this analysis suggests that GDP weights seem not to reflect the actual representation of countries within the monetary policy decision process of the ECB.

The representation of regional interests within a federal central bank like the ECB has received much attention in recent years. One strand of the literature addresses the question whether there is any empirical evidence of regional voting behaviour within a federal central bank. Berger and De Haan (2002) show that within the Bundesbank's Governing Council the probability of a regional representative to vote against the majority vote increased in the difference between their respective regional and national economic developments, in particular inflation and real GDP growth. Similar indications for the actual ECB policy and the US Federal Open Market Committee are provided by Heinemann and Hüfner (2004) and Meade and Sheets (2005), respectively. Another strand of the literature investigates whether misrepre-

\footnotetext{
${ }^{17}$ This assumption is also in accordance with the ECB's official statements: "We all know that the very existence of a single monetary policy and thereby a uniform policy interest rate across the euro area countries does not allow using monetary policy to influence output growth differentials across euro area countries.(...) Addressing 'unsatisfactory' output growth performances in individual countries must be tackled by properly designed national policies in the fiscal and structural domains." (Trichet, 2007)
} 


\begin{tabular}{|c|c|c|c|c|c|}
\hline & GDP & capital key & equal & voting & implicit \\
\hline AUS & 0.015 & 0.015 & 0.050 & 0.042 & 0.055 \\
\hline BEL & 0.017 & .018 & 0.054 & 0.030 & 0.055 \\
\hline FIN & 0.011 & 0.013 & 0.043 & 0.048 & 0.055 \\
\hline FRA & 0.071 & 0.082 & 0.047 & 0.039 & 0.055 \\
\hline GER & 0.083 & 0.107 & 0.036 & 0.041 & 0.055 \\
\hline GRE & 0.017 & 0.024 & 0.075 & 0.073 & 0.055 \\
\hline IRE & 0.027 & 0.020 & 0.110 & 0.082 & 0.055 \\
\hline ITA & 0.076 & 0.086 & 0.041 & 0.048 & 0.055 \\
\hline NET & 0.077 & 0.081 & 0.104 & 0.112 & 0.055 \\
\hline POR & 0.014 & 0.022 & 0.058 & 0.042 & 0.055 \\
\hline SPA & 0.061 & 0.069 & 0.062 & 0.067 & 0.055 \\
\hline
\end{tabular}

Table 5: Mean of weighted absolute cyclical stress $\left(1 / T \sum_{t} w_{j}\left|S_{j, t}^{c y c}\right|\right)$ using different weighting schemes, in percent, 1999-2006

sentation in federal central banks can be rationalised on economic grounds. Papers by Berger and Müller (2007) and Hefeker and Gros (2002), which set-up a simple two-country models of a monetary union, show that a perfect match between economic size and voting rights is rarely optimal. Thus, the main conclusion to draw from this literature for our paper is that other weighting schemes than GDP shares to produce euro area aggregates might be relevant for the monetary policy decision process within the ECB Governing Council.

An alternative economic weighting scheme could be the capital key, which is defined as the fully paid-up subscriptions of euro area national central banks to the capital of the ECB. Given its definition as the unweighted average of the shares of the member countries in the total population and gross domestic product of the EU, the capital key's high correlation with GDP weights is not surprising (see Figure 10). Apart from economic considerations, the weighting of country-specific information in the ECB's Governing Council could also be influenced by institutional characteristics of the decision-making body. A rather extreme interpretation of the political process would be to assume that each country is represented equally and is only interested in optimising monetary policy for its own population. This would imply that each country-specific stress level receives the same weight. As an extension to this so-called "one country, one vote" principle, the statutes of the ECB state that the voting rights are equally allocated among the members of the Governing Council. Thus, each of the 6 members of the Executive Board and each national central bank governor has one vote. If we 
Figure 10: Weighting schemes for euro area aggregation

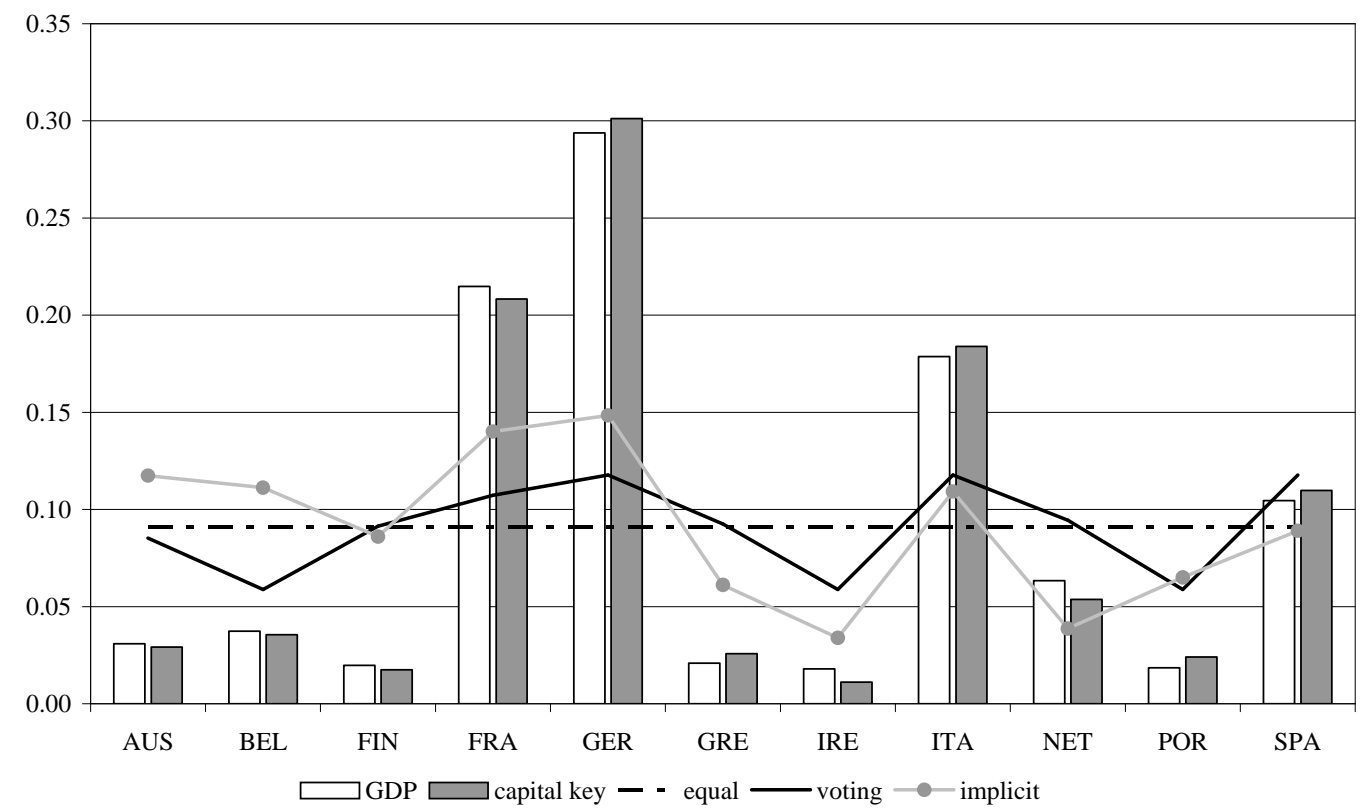

consider that decisions are taken by simple majority and if we assume that each member of the Governing Council is just a representative of his or her home country, we get a weighting scheme that takes the country distribution of voting rights into account. The basic difference to the equal weighting scheme is that countries like France, Germany, Italy and Spain, which were for most of the 1999-2006 period represented in the Executive Board, get a higher weight, whereas the opposite is true for countries like Belgium, Ireland and Portugal, which haven't been represented in the Executive Board yet. The common characteristic of the two institutional weighting schemes is that compared with their economic weights the three largest economies (France, Germany and Italy) are underrepresented, whereas the small economies (Austria, Belgium, Finland, Greece, Ireland, the Netherlands and Portugal) are overrepresented.

With each of these alternative weighting schemes we proceed as with our baseline GDP weights. We first aggregate country-specific expectations to euro area aggregates and estimate a euro area Taylor rule. Figure 11 shows that the evolution of expectations under the different weighting schemes is highly correlated; the pairwise correlation coefficients all lie above $90 \%$. However, since under equal and voting weights the small countries with high trend growth rates of GDP and prices get a higher weight than their relative eco- 
Figure 11: Area wide expectations using different weighting schemes
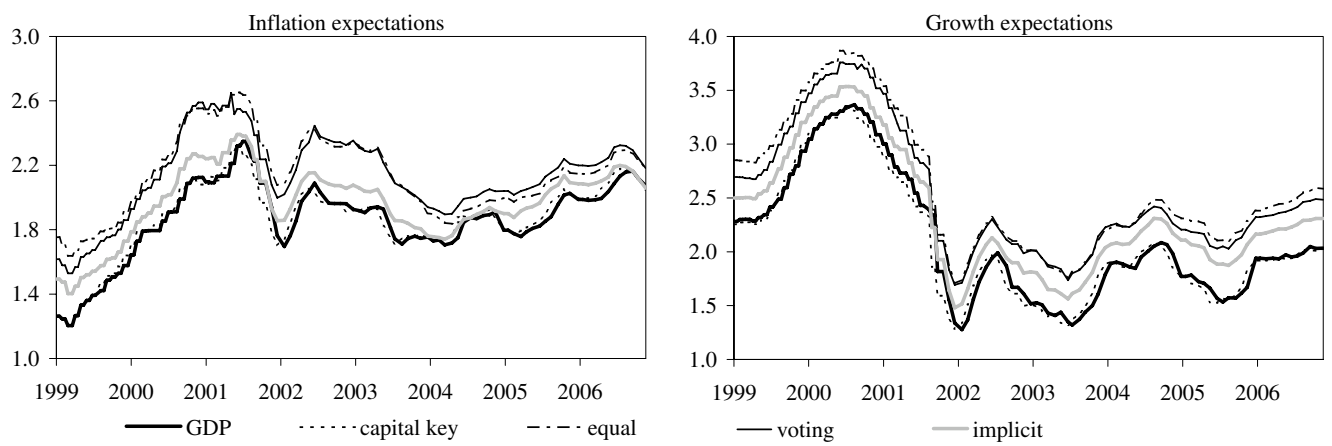

\begin{tabular}{|c|c|c|c|c|}
\hline & capital key & equal & voting & implicit \\
\hline Interest rate smoothing $\left(\rho_{E A}\right)$ & $\begin{array}{r}0.91^{* *} \\
(0.02)\end{array}$ & $\begin{array}{r}0.87^{* *} \\
(0.04)\end{array}$ & $\begin{array}{r}0.89^{* *} \\
(0.03)\end{array}$ & $\begin{array}{r}0.90^{* *} \\
(0.03)\end{array}$ \\
\hline Neutral real rate $\left(\alpha_{E A}\right)$ & $\begin{array}{r}0.51^{* *} \\
(0.06)\end{array}$ & $\begin{array}{r}0.30^{* *} \\
(0.04)\end{array}$ & $\begin{array}{r}0.31^{* *} \\
(0.05)\end{array}$ & $\begin{array}{r}0.41^{* *} \\
(0.05)\end{array}$ \\
\hline Inflation expectations $\left(\beta_{E A}\right)$ & $\begin{array}{r}2.06^{* *} \\
(0.36)\end{array}$ & $\begin{array}{r}1.90^{* *} \\
(0.27)\end{array}$ & $\begin{array}{r}1.65^{* *} \\
(0.30)\end{array}$ & $\begin{array}{r}1.99^{* *} \\
(0.36)\end{array}$ \\
\hline Expected output growth $\left(\gamma_{E A}\right)$ & $\begin{array}{r}1.60^{* *} \\
(0.17)\end{array}$ & $\begin{array}{r}1.20^{* *} \\
(0.14)\end{array}$ & $\begin{array}{r}1.40^{* *} \\
(0.17)\end{array}$ & $\begin{array}{r}1.52^{* *} \\
(0.17)\end{array}$ \\
\hline
\end{tabular}

Notes: Heteroscedasticity and autocorrelation consistent standard errors shown in parentheses. ${ }^{*}$ denotes significance at $10 \%$, and ${ }^{* *}$ significance at $5 \%$.

Table 6: Estimation results for the Taylor rule using different weighting schemes, 1999-2006

nomic size, the aggregate evolution of inflation and growth expectations is shifted upwards. This shift is also reflected in the estimate for $\alpha_{E A}$, which is lower than under the two economically based weighting schemes (see Table 6 ). Interestingly, the explanatory power of all Taylor rule regressions is as good as identical $\left(R^{2} \approx 98.2 \%\right)$ and all the estimates are significant. The deviations of the other reaction coefficients from our baseline estimates are only of minor magnitude. While the coefficients on inflation expectations are somewhat higher, the coefficients on growth expectations are slightly lower in the case of equal and voting weights and marginally higher when the capital key is used for the aggregation to euro area expectations. Thus, the weighting scheme used to aggregate country-specific expectations to euro area expectations doesn't seem to matter for the validity of the Taylor rule model to describe the ECB's interest rate policy.

In a second step we calculate total stress for the euro area (see Figure 12) 
and the country decomposition of its cyclical component (see Table 5). Not surprisingly, a weighting of the countries according to the capital key yields results, which are very close to those obtained under GDP weights. Again, total EMU stress has an upward trend, and the five largest member countries account on average for almost $80 \%$ of its cyclical component.

However, when countries are weighted equally or according to their voting rights, the synchronisation results point in the opposite direction. In these cases, smaller countries, which are given a weight higher than their economic share, automatically contribute more to the cyclical component of total EMU stress. As a consequence, the long-run pattern of cyclical EMU stress changes direction. Whereas we previously could not find evidence of a downward trend in overall cyclical stress, these other two weighting schemes result in a significant downward trend. Thus, when smaller countries receive a substantially larger weight as compared to their economic size, cyclical developments have become more synchronised since the introduction of the monetary union.

The result that the cyclical component of aggregate EMU stress is unevenly distributed across member countries, when we use the weights discussed so far, leads us to propose an alternative weighting scheme, which can be directly derived from our stress indicator. For a two country case where the weights attributed to country 1 and country 2 are $w$ and $1-w$, respectively, it can be shown that the cyclical components of stress can be written as

$$
\begin{aligned}
S_{1, t}^{c y c} & =(w-1)\left[\beta_{E A}\left(E_{t} \pi_{1, t+k}-\bar{\pi}_{1}-E_{t} \pi_{2, t+k}+\bar{\pi}_{2}\right)+\right. \\
& \left.+\gamma_{E A}\left(E_{t} \Delta y_{1, t+k}-\Delta \bar{y}_{1}-E_{t} \Delta y_{2, t+k}+\Delta \bar{y}_{2}\right)\right] \\
S_{2, t}^{c y c} & =w\left[\beta_{E A}\left(E_{t} \pi_{1, t+k}-\bar{\pi}_{1}-E_{t} \pi_{2, t+k}+\bar{\pi}_{2}\right)+\right. \\
& \left.+\gamma_{E A}\left(E_{t} \Delta y_{1, t+k}-\Delta \bar{y}_{1}-E_{t} \Delta y_{2, t+k}+\Delta \bar{y}_{2}\right)\right],
\end{aligned}
$$

where we replaced the area wide aggregates in Equation (5) by their weighted country averages. As the two terms in brackets are identical, the following equality holds

$$
w S_{1, t}^{c y c}=(w-1) S_{2, t}^{c y c},
$$

which implies that the mean of weighted absolute cyclical stress should be equal across countries. Under the assumption that this equality also holds in the n-country case, the stress indicators can be used to derive the so-called implicit weights, we interpret as the actual representation of each member country in the ECB Governing Council.

In the actual political process, the small countries (Austria, Belgium, Finland, Greece, Ireland and Portugal) have implicitly received a rather large 
Figure 12: Total stress in the euro area using different weighting schemes
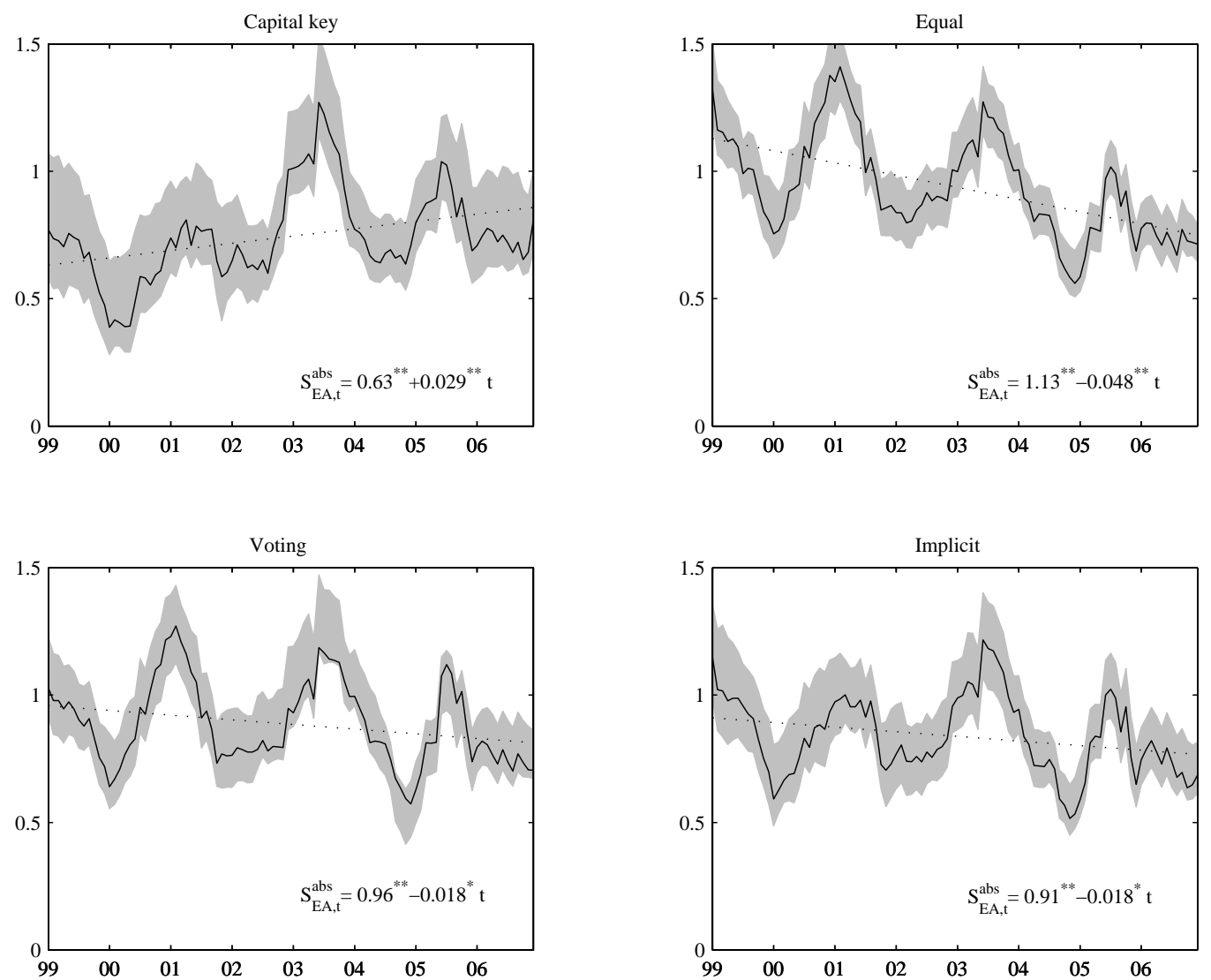

Notes: The shaded areas are the 95 percent confidence intervals, which are calculated as the 0.025 and 0.975 quantile of the sampling distribution obtained from a bootstrap procedure with 1,000 replications. As the distribution of country-specific absolute stress is truncated at zero and hence skewed to the right, the confidence intervals around the means (which are computed using the point estimates of the baseline Taylor rule regression) are asymmetric. The dotted lines are linear trends of the means, whose estimated intercepts and (annualised) slopes are indicated in each graph. ${ }^{*}$ denotes significance at $10 \%$, and ${ }^{* *}$ significance at $5 \%$.

weight relative to their economic size. Thus, these countries are overrepresented in the ECB's decision making process. When compared with the institutional weights (equal and voting) especially Austria and Belgium stand out, whose political influence turns out to be almost as pronounced as the German or the French. The three largest economies (France, Germany and Italy) are clearly underrepresented, when implicit weights are compared with economic weights. However, implicit weights are larger than those having been derived from the distribution of voting rights or from the "one country, 
one vote" principle.

The area wide expectations that result from the use of implicit weights lie between those obtained when using economic weights and those obtained using institutional weights (see Figure 11). As a consequence, the estimate for $\alpha_{E A}$ is lower than with economic weights and higher than with institutional weights (see Table 6). The remaining coefficients of the Taylor rule do not appear to systematically differ from those of the baseline regression. Although this weighting scheme lies in between the economic and the institutional scenarios, the conclusion with respect to business cycle synchronisation remains clear cut. As before with institutional weights, aggregate euro area cyclical stress has significantly decreased over time.

\section{Conclusions}

In this paper we define monetary stress in a particular member country of the EMU as the difference between the ECB main refinancing rate and the policy interest rate that would prevail if that country would have been able to follow a for that country "optimal" monetary policy. Instead of extrapolating individual central bank behaviour before the introduction of the euro into the EMU period, we are the first to assume that the actual reaction function of the ECB is a good description of this "optimal" monetary policy at the country level. EMU countries voluntarily decided to participate in the monetary union, i.e. to adopt the institutional set up of the ECB. In this case, asymmetries in inflation and cyclical output developments across countries generate differences between the actual interest rate and the one that would prevail if the reaction function of the ECB were applied to the national level.

The reported monetary stress levels are sizeable. From a country perspective, on average interest rates should have been 2.8 percentage points higher in Ireland and 0.6 percentage points lower in Germany. The structurally lower inflation and growth rate kept stress levels positive in Germany throughout our sample. On the other hand-besides Ireland-Greece, Portugal and Spain mostly experienced negative stress levels. This has mainly been due to persistent higher inflation expectations in those countries. On top of that, in Greece and Ireland also growth expectations were higher. These differences are all of a structural nature and thereby not necessarily the focus of monetary policy. However, not only do stress levels vary considerably across the EMU countries, the variation over time is also quite substantial. For instance, although average stress levels were close to zero in the Netherlands and in Finland, rather pronounced cyclical patterns are 
visible there. Overall, actual monetary policy of the ECB seems to have been rather appropriate for countries like Austria, Belgium, France and Italy. For Italy, higher inflation and lower growth neutralized each other.

When aggregating the country-specific monetary stress indicators to the euro area level, we first take a normative approach and weigh each country according to its economic size. The resulting indicator reveals that there are times in which output growth and inflation cycles are more synchronised across the euro area and, hence, the ECB policy is more in line with the preferences of each individual member country. However, the data does not reflect a general tendency of cycles to become more similar over time. Hence, we do not find evidence in favour of the euro area being a self-enforcing optimal currency area in such a scenario.

As noted by, e.g. Berger (2006), economic size does not represent the actual voting distribution of the ECB Governing Council. ${ }^{18}$ If we redo our analysis, but this time use e.g. the voting distribution within the Governing Council as weighting scheme, the resulting aggregate monetary stress indicator does point towards convergence of business cycles within the euro area. Apparently, when aswering the question whether the euro area is a self-enforcing optimal currency area it is important to first take a stand on the actual weight countries are giving in the monetary policy decision process of the ECB.

Under the assumption that over time the burden of a common monetary policy is equally distributed amongst the member countries, our framework generates a weighting scheme in which mainly the larger economies (Germany, France, Italy and Spain) have on average been underrepresented in the political decision process as compared to their economic size. On the other hand, growth and inflation developments of the small and highly developed member states (Austria, Belgium, Finland) did - relative to their economic size - not bear a large part of the overall burden over the past eight years. Hence, this implicit weighting scheme shows quite some resemblence with our voting weighting scheme and indeed suggests a steady increase of business and inflation cycle synchronisation within the euro area. It implies a reduction of approximately 15 percent in monetary stress levels in the euro area during 1999-2006.

As a final note, in this paper we have only focussed upon monetary stress and thereby costs associated to differences in growth and inflation cycles

\footnotetext{
${ }^{18}$ According to Berger (2006) "The ECB is clearly an 'extreme' case ... the misrepresentation indicator for the ECB's Governing Council reached values about seven time higher than for the Fed's FOMC or the Bundesbanks's Zentralbankrat. Without reform, EMU enlargement could lead to even wider gaps between economic and political weights by the 2010s."
} 
within the euro area. Of course, there are also benefits associated to having a monetary union. For instance, it facilitates trade and fosters competition by enlarging markets. It is well possible that these and other benefits outweigh the costs associated with monetary stress.

\section{References}

Ball, L. (1999). Efficient rules for monetary policy. International Finance, 2(1):63-83.

Berger, H. (2006). Optimal central bank design: Benchmarks for the ECB. Review of International Organizations, 1:207-235.

Berger, H. and De Haan, J. (2002). Are small countries too powerful within the ECB? Atlantic Economic Journal, 30:1-20.

Berger, H. and Müller, T. (2007). How should large and small countries be represented in a currency union? Public Choice, 132:471-484.

Carlson, J. and Parkin, M. (1975). Inflation expectations. Economica, 42(166):123-138.

Carstensen, K. and Colavecchio, R. (2005). The ECB monetary policy and its Taylor-type reaction function. Paper presented on the 6th IWH Workshop in Macroeconometrics, Halle.

Castelnuovo, E. (2007). Taylor rules and interest rate smoothing in the euro area. The Manchester School, 75(1):1-16.

Clarida, R., Galí, J., and Gertler, M. (1998). Monetary policy rules in practise: Some international evidence. European Economic Review, 42:10331067.

Cragg, J. G. and Donald, S. G. (1993). Testing identifiability and specification in instrumental variable models. Econometric Theory, 9:222-240.

De Haan, J., Eijffinger, S. C., and Waller, S. (2005). The European Central Bank. Credibility, Transparency, and Centralization. MIT Press. CESifo Book Series.

English, W., Nelson, W., and Sack, B. (2003). Interpreting the significance of the lagged interest rate in estimated monetary policy rules. Contributions to Macroeconomics, 3(1):Article 5. 
Fendel, R. and Frenkel, M. (2005). Inflation differentials in the euro area: Did the ECB care? Applied Economics (forthcoming).

Fendel, R. and Frenkel, M. (2006). Five years of single monetary policy in practice: Is the ECB rule-based? Contemporary Economic Policy, $24(1): 106-115$.

Flaig, G. and Wollmershäuser, T. (2007). Does the euro-zone diverge? A stress indicator for analyzing trends and cycles in real GDP and inflation. In Franz, W., Ramser, H. J., and Stadler, M., editors, Dynamik internationaler Märkte, pages 15-41. Mohr Siebeck, Tübingen.

Fourçans, A. and Vranceanu, R. (2004). The ECB interest rate rule under the Duisenberg presidency. European Journal of Political Economy, 20:579595.

Garnier, J. and Wilhelmsen, B.-R. (2005). The natural real interest rate and the output gap in the euro area: A joint estimation. ECB Working Papers Series No. 546.

Geberding, C., Worms, A., and Seitz, F. (2004). How the bundesbank really conducted monetary policy: An analysis based on real-time data. Bundesbank Discussion Paper No. 25/2004.

Gerdesmeier, D. and Roffia, B. (2004). Empirical estimates of reaction functions for the euro area. Swiss Journal of Economics and Statistics, 140(1):37-66.

Giannone, D. and Reichlin, L. (2006). Trends and cycles in the euro area. How much heterogeneity and should we worry about it? ECB Working Papers Series No. 595.

Gorter, J., Jacobs, J., and De Haan, J. (2007). Taylor rules for the ECB using consensus data. DNB Working Paper No.160.

Harvey, D., Leybourne, S., and Newbold, P. (2001). Analysis of a panel of UK macroeconomic forecasts. Econometrics Journal, 4:37-55.

Hayo, B. and Hofmann, B. (2006). Comparing monetary policy reaction functions: ECB versus bundesbank. Empirical Economics, 31:645-662.

Hefeker, C. and Gros, D. (2002). One size must fil all: National divergences in a monetary union. German Economic Review, 3(3):247-262. 
Heinemann, F. and Hüfner, F. P. (2004). Is the view from the eurotower purely European? National divergence and ECB interest rate policy. Scottish Journal of Political Economy, 51(4):544-558.

Heinemann, F. and Ullrich, K. (2006). The impact of EMU on inflation expectations. Open Economies Review, 17:175-195.

Isiklar, G., Lahiri, K., and Loungani, P. (2006). How quickly do forecasters incorporate news? Evidence from cross-country surveys. Journal of Applied Econometrics, 21:703-725.

Jondeau, E. and Sahuc, J.-G. (2005). Testing heterogeneity within the euro area using a structural multi-country model. mimeo.

Laubach, T. and Williams, J. (2003). Measuring the natural rate of interest. Review of Economics and Statistics, 85(4):1063-1070.

Loungani, P. (2001). How accurate are private sector forecasts? Crosscountry evidence from consensus forecasts of output growth. International Journal of Forecasting, 17:419-432.

Meade, E. E. and Sheets, D. N. (2005). Regional influences on FOMC voting patterns. Journal of Money, Credit, and Banking, 37(4):661-677.

Orphanides, A. (2001). Monetary policy rules based on real-time data. American Economic Review, 91(4):964-985.

Rudebusch, G. (2002). Term structure evidence on interest rate smoothing and monetary policy inertia. Journal of Monetary Economics, 49:11611187.

Sauer, S. and Sturm, J.-E. (2003). Using Taylor rules to understand ECB monetary policy. CESifo Working Paper, 1110.

Sauer, S. and Sturm, J.-E. (2007). Using Taylor rules to understand ECB monetary policy. German Economic Review, 8(3):375-398.

Stock, J. H. and Yogo, M. (2005). Testing for weak instruments in linear iv regression. In Andrews, D. W. and Stock, J. H., editors, Identification and Inference for Econometric Models: Essays in Honor of Thomas Rothenberg, pages 80-108. Cambridge University Press, Cambridge.

Surico, P. (2003). Asymmetric reaction functions for the euro area. Oxford Review of Economic Policy, 19(1):44-57. 
Tanner, E. C. (1999). Exchange market pressure and monetary policy Asia and Latin America in the 1990s. IMF Working Paper No. 99/114.

Taylor, J. (1993). Discretion versus policy rules in practice. CarnegieRochester Conference Series on Public Policy, 39:195-214.

Trichet, J.-C. (2007). Governance and convergence: the state of play in the euro area. Speech delivered at a conference entitled "Euro zone converging or drifting apart?" in Brussels, 28 February 2007, organised by the European Parliament (Committee of Economic and Monetary Affairs).

Ullrich, K. (2003). A comparison between the Fed and the ECB: Taylor rules. ZEW Discussion Paper No. 03-19.

Van Poeck, A., Vanneste, J., and Veiner, M. (2007). Exchange rate regimes and exchange market pressure in the new EU member states. Journal of Common Market Studies, 45(2):459-485.

Walsh, C. (2003). Implications of a Changing Economic Structure for the Strategy of Monetary Policy, pages 297-348. Federal Reserve Bank of Kansas City. Jackson Hole Symposium.

Weymark, D. N. (1997). Measuring exchange market pressure and intervention in interdependent economies: A two-country model. Review of International Economics, 5(1):72-82.

Woodford, M. (2003). Interest and Prices: Foundations of a Theory of Monetary Policy. Princeton University Press, Princeton, N.J.

\section{Appendix}

\section{A Quantifying qualitative inflation expectations}

The most widely used method for quantifying qualitative inflation expectations goes back to a paper by Carlson and Parkin (1975). Their method assumes that individual responses about the future value of a variable are based on the respondents' subjective probability density function. Respondents report a variable to go up or down if the median of their subjective probability distribution lies above or below an indifference interval. The upper and lower boundary of the indifference interval which mark the socalled just noticeable difference are derived from the respondents' aggregate 
answers and the time-series properties of past realizations of the macroeconomic variable under consideration. Most crucially, Carlson and Parkin (1975) assumed the aggregate distribution to be normal with symmetric and time-invariant boundaries that are allowed to vary across countries. Additionally, they imposed that the average value of past realizations and the average value of expectations must be equal, which is typically referred to as the unbiasedness of expectations.

As these assumptions are rather restrictive a variant of the Carlson-Parkin method has been proposed by Heinemann and Ullrich (2006). In contrast to the standard Carlson-Parkin method they do not implicitly derive the just noticeable difference from the qualitative survey responses and from the statistical properties of the reference time-series, but from a special question in the survey in which they directly query the respondents' boundaries of the indifference interval. In practical terms, the respondents were asked to indicate the percentage point decrease (increase) of inflation that makes the respondent mark 'go down' ('go up') in the survey. Heinemann and Ullrich (2006) assume that these boundaries are constant over time and they estimate the lower boundary $a_{t}$ to be -0.24 and the upper boundary $b_{t}$ to be 0.22 .

The formula for calculating the expected change in inflation is given by

$$
E_{t} \Delta \pi_{t+k}=\frac{b_{t} \Phi^{-1}\left(\mathrm{DOWN}_{t}\right)-a_{t} \Phi^{-1}\left(1-\mathrm{UP}_{t}\right)}{\Phi^{-1}\left(\mathrm{DOWN}_{t}\right)-\Phi^{-1}\left(1-\mathrm{UP}_{t}\right)}
$$

where $\Phi$ is the cumulative distribution function of an assumed standard normal variate, and $\mathrm{UP}_{t}$ and $\mathrm{DOWN}_{t}$ denote the percentage of the responses expecting a rise and a fall in inflation.

\section{B Data}


Figure 13: Inflation expectations
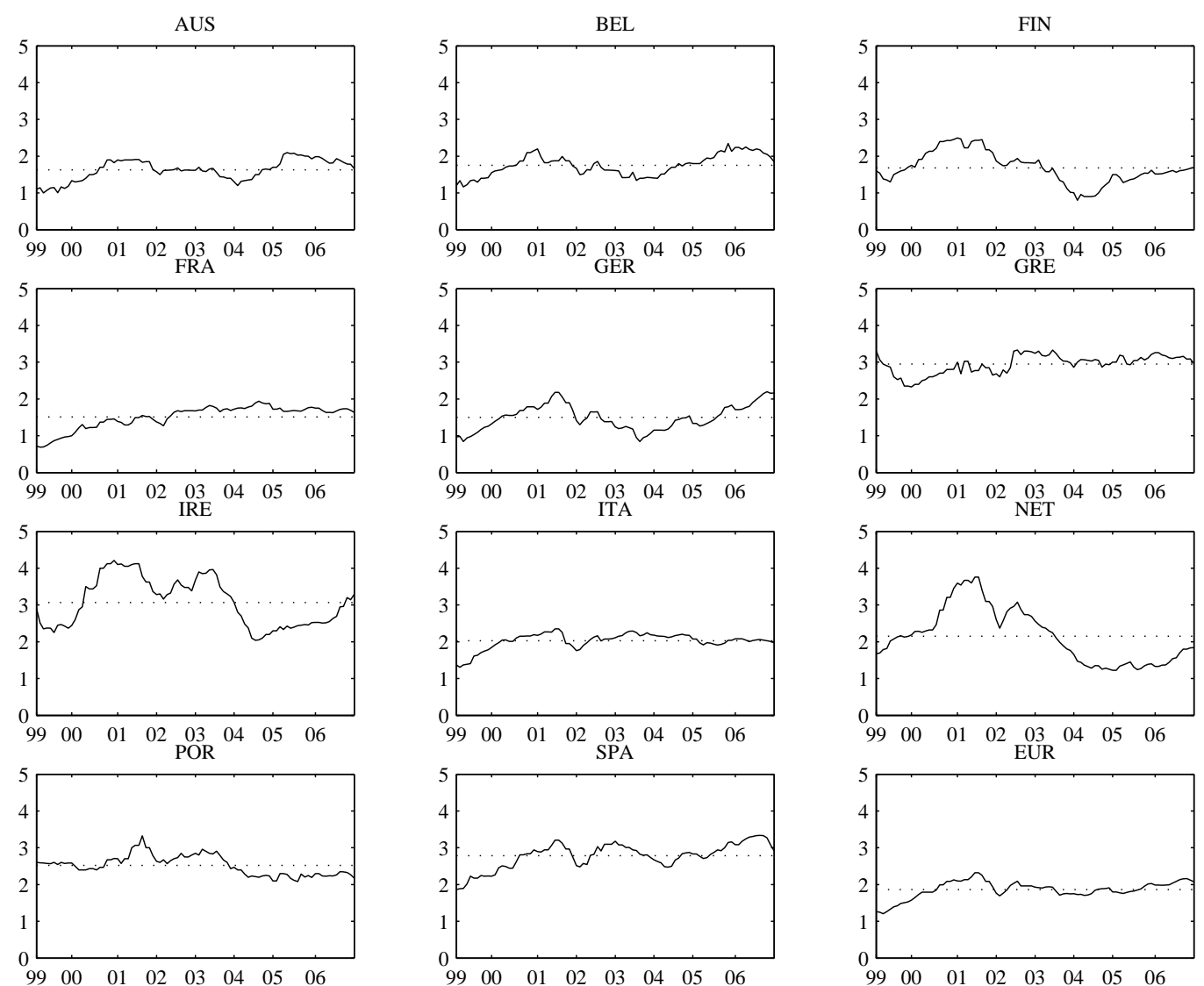

Notes: Solid line: 12-months ahead consensus forecasts of inflation; dotted line: mean. Source: Consensus Economics Inc. 
Figure 14: Growth expectations
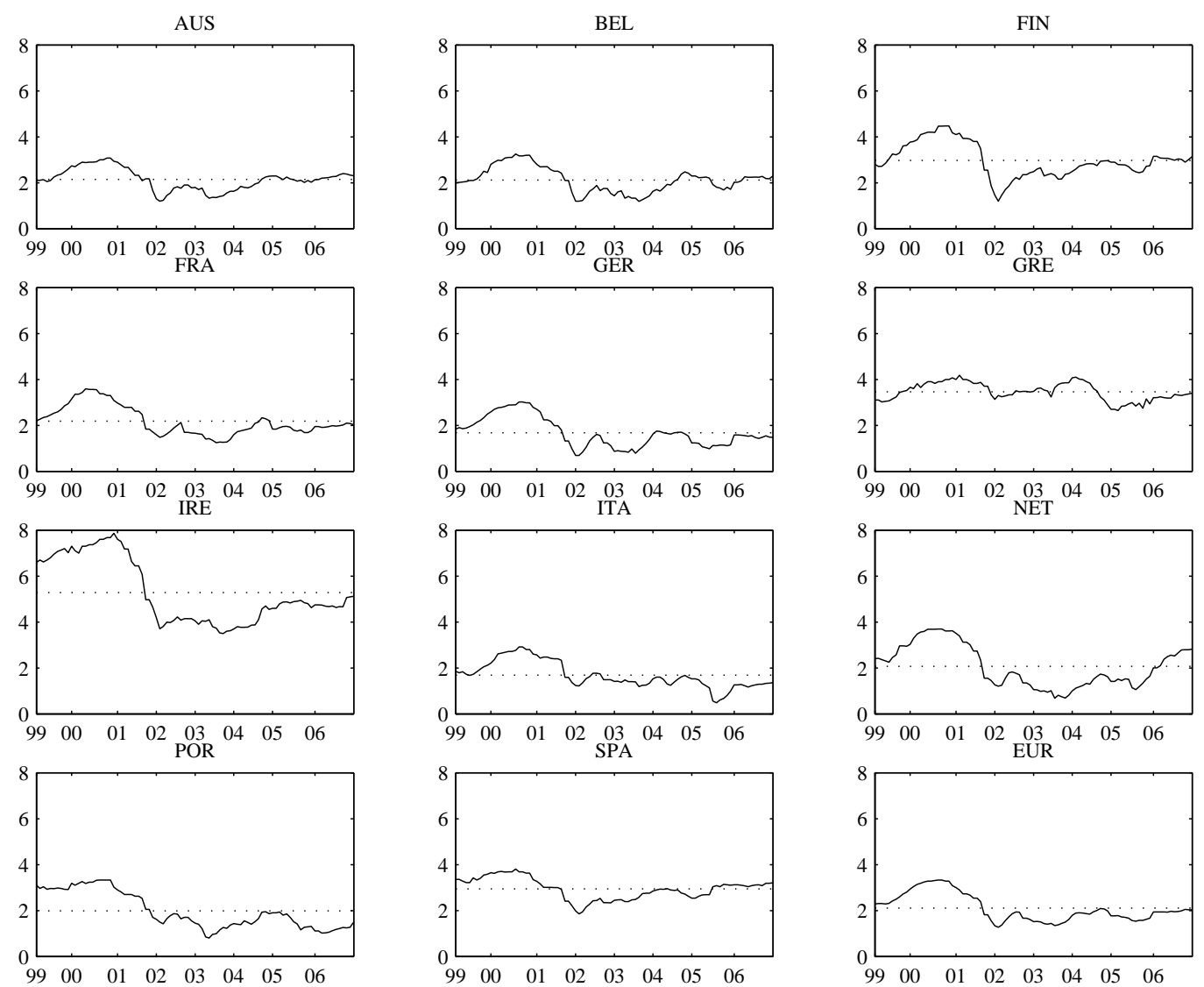

Notes: Solid line: 12-months ahead consensus forecasts of GDP growth; dotted line: mean. Source: Consensus Economics Inc. 


\section{CESifo Working Paper Series}

for full list see www.cesifo-group.org/wp

(address: Poschingerstr. 5, 81679 Munich, Germany, office@cesifo.de)

2188 Sándor Csengődi and Dieter M. Urban, Foreign Takeovers and Wage Dispersion in Hungary, January 2008

2189 Joerg Baten and Andreas Böhm, Trends of Children's Height and Parental Unemployment: A Large-Scale Anthropometric Study on Eastern Germany, 1994 2006, January 2008

2190 Chris van Klaveren, Bernard van Praag and Henriette Maassen van den Brink, A Public Good Version of the Collective Household Model: An Empirical Approach with an Application to British Household Data, January 2008

2191 Harry Garretsen and Jolanda Peeters, FDI and the Relevance of Spatial Linkages: Do third Country Effects Matter for Dutch FDI?, January 2008

2192 Jan Bouckaert, Hans Degryse and Theon van Dijk, Price Discrimination Bans on Dominant Firms, January 2008

2193 M. Hashem Pesaran, L. Vanessa Smith and Takashi Yamagata, Panel Unit Root Tests in the Presence of a Multifactor Error Structure, January 2008

2194 Tomer Blumkin, Bradley J. Ruffle and Yosef Ganun, Are Income and Consumption Taxes ever really Equivalent? Evidence from a Real-Effort Experiment with Real Goods, January 2008

2195 Mika Widgrén, The Impact of Council's Internal Decision-Making Rules on the Future EU, January 2008

2196 Antonis Adam, Margarita Katsimi and Thomas Moutos, Inequality and the Import Demand Function, January 2008

2197 Helmut Seitz, Democratic Participation and the Size of Regions: An Empirical Study Using Data on German Counties, January 2008

2198 Theresa Fahrenberger and Hans Gersbach, Minority Voting and Long-term Decisions, January 2008

2199 Chiara Dalle Nogare and Roberto Ricciuti, Term Limits: Do they really Affect Fiscal Policy Choices?, January 2008

2200 Andreas Bühn and Friedrich Schneider, MIMIC Models, Cointegration and Error Correction: An Application to the French Shadow Economy, January 2008

2201 Seppo Kari, Hanna Karikallio and Jukka Pirttilä, Anticipating Tax Change: Evidence from the Finnish Corporate Income Tax Reform of 2005, January 2008 
2202 Walter Krämer and André Güttler, On Comparing the Accuracy of Default Predictions in the Rating Industry, January 2008

2203 Syed M. Ahsan and Panagiotis Tsigaris, The Efficiency Loss of Capital Income Taxation under Imperfect Loss Offset Provisions, January 2008

2204 P. Mohnen, F. C. Palm, S. Schim van der Loeff and A. Tiwari, Financial Constraints and other Obstacles: Are they a Threat to Innovation Activity?, January 2008

2205 Sascha O. Becker and Mathias Hoffmann, Equity Fund Ownership and the CrossRegional Diversification of Household Risk, January 2008

2206 Pedro R. D. Bom and Jenny E. Ligthart, How Productive is Public Capital? A MetaAnalysis, January 2008

2207 Martin Werding, Ageing and Productivity Growth: Are there Macro-level Cohort Effects of Human Capital?, January 2008

2208 Frederick van der Ploeg and Steven Poelhekke, Globalization and the Rise of MegaCities in the Developing World, February 2008

2209 Sara Biancini, Regulating National Firms in a Common Market, February 2008

2210 Jin Cao and Gerhard Illing, Liquidity Shortages and Monetary Policy, February 2008

2211 Mathias Kifmann, The Design of Pension Pay Out Options when the Health Status during Retirement is Uncertain, February 2008

2212 Laszlo Goerke, Tax Overpayments, Tax Evasion, and Book-Tax Differences, February 2008

2213 Jun-ichi Itaya and Heinrich W. Ursprung, Price and Death, February 2008

2214 Valentina Bosetti, Carlo Carraro and Emanuele Massetti, Banking Permits: Economic Efficiency and Distributional Effects, February 2008

2215 Assar Lindbeck, Mårten Palme and Mats Persson, Social Interaction and Sickness Absence, February 2008

2216 Gary E. Bolton and Axel Ockenfels, The Limits of Trust in Economic Transactions Investigations of Perfect Reputation Systems, February 2008

2217 Hartmut Egger and Peter Egger, The Trade and Welfare Effects of Mergers in Space, February 2008

2218 Dorothee Crayen and Joerg Baten, Global Trends in Numeracy 1820-1949 and its Implications for Long-Run Growth, February 2008

2219 Stephane Dees, M. Hashem Pesaran, L. Vanessa Smith and Ron P. Smith, Identification of New Keynesian Phillips Curves from a Global Perspective, February 2008 
2220 Jerome L. Stein, A Tale of Two Debt Crises: A Stochastic Optimal Control Analysis, February 2008

2221 Michael Melvin, Lukas Menkhoff and Maik Schmeling, Automating Exchange Rate Target Zones: Intervention via an Electronic Limit Order Book, February 2008

2222 Raymond Riezman and Ping Wang, Preference Bias and Outsourcing to Market: A Steady-State Analysis, February 2008

2223 Lars-Erik Borge and Jørn Rattsø, Young and Old Competing for Public Welfare Services, February 2008

2224 Jose Apesteguia, Steffen Huck, Jörg Oechssler and Simon Weidenholzer, Imitation and the Evolution of Walrasian Behavior: Theoretically Fragile but Behaviorally Robust, February 2008

2225 Walter Krämer, Long Memory with Markov-Switching GARCH, February 2008

2226 António Afonso and Christophe Rault, What do we really Know about Fiscal Sustainability in the EU? A Panel Data Diagnostic, February 2008

2227 Sergey M. Kadochnikov and Igor M. Drapkin, Market Structure, Technological Gap and Vertical Linkage Effects from Foreign Direct Investment, February 2008

2228 Guglielmo Maria Caporale, Davide Ciferri and Alessandro Girardi, Fiscal Shocks and Real Exchange Rate Dynamics: Some Evidence for Latin America, February 2008

2229 Scott Alan Carson, Geography and Insolation in $19^{\text {th }}$ Century US African-American and White Statures, February 2008

2230 Wolfgang Buchholz and Jan Schumacher, Discounting and Welfare Analysis Over Time: Choosing the $\eta$, February 2008

2231 M. Hashem Pesaran, Christoph Schleicher and Paolo Zaffaroni, Model Averaging in Risk Management with an Application to Futures Markets, February 2008

2232 Wilhelm Kohler, Offshoring: Why Do Stories Differ?, February 2008

2233 Stefan Bach, Giacomo Corneo and Viktor Steiner, Effective Taxation of Top Incomes in Germany, 1992-2002, February 2008

2234 Robert S. Chirinko, $\sigma:$ The Long And Short Of It, February 2008

2235 Volker Grossmann and Holger Strulik, Should Continued Family Firms Face Lower Taxes than other Estates?, February 2008

2236 Guido Tabellini, The Scope of Cooperation: Values and Incentives, February 2008

2237 Heinrich W. Ursprung and Christian Wiermann, Reputation, Price, and Death: An Empirical Analysis of Art Price Formation, March 2008 
2238 Hans Fehr and Christian Habermann, Private Retirement Savings in Germany: The Structure of Tax Incentives and Annuitization, March 2008

2239 Joseph Francois and Ian Wooton, Market Structure and Market Access, March 2008

2240 Hiroyuki Kasahara and Beverly Lapham, Productivity and the Decision to Import and Export: Theory and Evidence, March 2008

2241 Gary E. Bolton and Axel Ockenfels, Does Laboratory Trading Mirror Behavior in Real World Markets? Fair Bargaining and Competitive Bidding on EBay, March 2008

2242 Atsushi Oshima, B. Ravikumar and Raymond Riezman, Entrepreneurship, Organization Capital and the Evolution of the Firm, March 2008

2243 Walter Krämer and Sebastian Schich, Large-Scale Disasters and the Insurance Industry, March 2008

2244 Leif Danziger, Adjustment Costs, Inventories and Output, March 2008

2245 Anne van Aaken, Lars P. Feld and Stefan Voigt, Power over Prosecutors Corrupts Politicians: Cross Country Evidence Using a New Indicator, March 2008

2246 Hans-Christian Heinemeyer, Max-Stephan Schulze and Nikolaus Wolf, Endogenous Borders? The Effects of New Borders on Trade in Central Europe 1885-1933, March 2008

2247 Johannes Becker and Clemens Fuest, Tax Competition - Greenfield Investment versus Mergers and Acquisitions, March 2008

2248 Giorgio Bellettini and Hubert Kempf, Why not in your Backyard? On the Location and Size of a Public Facility, March 2008

2249 Jose Luis Evia, Roberto Laserna and Stergios Skaperdas, Socio-Political Conflict and Economic Performance in Bolivia, March 2008

2250 Bas Jacobs and A. Lans Bovenberg, Optimal Taxation of Human Capital and the Earnings Function, March 2008

2251 Jan-Egbert Sturm and Timo Wollmershäuser, The Stress of Having a Single Monetary Policy in Europe, March 2008 